\title{
Micro- and Nanoscale Approaches in Antifungal Drug Discovery
}

\author{
Ronnie G. Willaert 1,2 \\ 1 Alliance Research Group VUB-UGent NanoMicrobiology (NAMI), IJRG VUB-EPFL NanoBiotechnology \& \\ NanoMedicine (NANO), Research Group Structural Biology Brussels, Vrije Universiteit Brussel, \\ 1050 Brussels, Belgium; Ronnie.Willaert@vub.be; Tel.: +32-26291846 \\ 2 Department Bioscience Engineering, University Antwerp, 2020 Antwerp, Belgium
}

Received: 7 May 2018; Accepted: 5 June 2018; Published: 11 June 2018

\begin{abstract}
Clinical needs for novel antifungal agents have increased due to the increase of people with a compromised immune system, the appearance of resistant fungi, and infections by unusual yeasts. The search for new molecular targets for antifungals has generated considerable research, especially using modern omics methods (genomics, genome-wide collections of mutants, and proteomics) and bioinformatics approaches. Recently, micro- and nanoscale approaches have been introduced in antifungal drug discovery. Microfluidic platforms have been developed, since they have a number of advantages compared to traditional multiwell-plate screening, such as low reagent consumption, the manipulation of a large number of cells simultaneously and independently, and ease of integrating numerous analytical standard operations and large-scale integration. Automated high-throughput antifungal drug screening is achievable by massive parallel processing. Various microfluidic antimicrobial susceptibility testing (AST) methods have been developed, since they can provide the result in a short time-frame, which is necessary for personalized medicine in the clinic. New nanosensors, based on detecting the nanomotions of cells, have been developed to further decrease the time to test antifungal susceptibility to a few minutes. Finally, nanoparticles (especially, silver nanoparticles) that demonstrated antifungal activity are reviewed.
\end{abstract}

Keywords: antifungal drug discovery; microfluidics; nanobiotechnology; omics-based approaches; antifungal susceptibility testing; nanomotion detection; nanoparticles

\section{Introduction}

Fungal infections are an extremely important health problem. Fungi infect about 1.2 billion people every year, yet their contribution to the global burden of disease is largely unrecognised [1,2]. Over 600 different fungi have been reported to infect humans. Most are "relatively" minor infections, but millions contract diseases that kill at least as many people as tuberculosis or malaria. More than 300 million people are affected by serious fungal infections worldwide. Invasive fungal infections are responsible for about 1.5 million deaths per year. Fungi are present everywhere in our environment and are, usually, harmless for people with a normal immune system. Fungal infections can be topical and local, such as infections on the skin or in the vaginal tract. Systemic infections arise when the fungi enter and proliferate in the bloodstream. Systemic fungal infections affect people with an altered immune system due to medical interventions (such as cancer therapy, organ transplantation, and immune-modulatory medications), immunosuppressive diseases (such as Acquired Immune Deficiency Syndrome (AIDS)) [3], or malnutrition (under- and overnutrition) [4-6].

The choice of available antifungal drugs to treat invasive fungal infections is limited, since only three structural classes of compounds are available, i.e., polyenes, azoles, and echinocandins. Antifungal therapy has become progressively more effective since the 1990s, however, no new 
antifungal classes have been reported since 2006 [7]. Current antifungal drugs show some limitations: Amphothericin B (a polyene antibiotic) displays a considerable toxicity and undesirable side effects [8,9], issues with pharmacokinetic properties (such as a short half-life of echinocandins) and activity spectrum, a small number of targets $[10,11]$, and they can interact with other drugs, such as chemotherapy agents and immunosuppressants [12,13]. The last approved antifungal (i.e., anidulafungin) by the European Medicines Agency and the Food and Drug Administration (FDA) dates back to 2006 [14]. There is an urgent need for safer and more effective antifungal drugs. Multiple types of antifungal compounds are in clinical development and these new agents have been recently reviewed [15-17].

Over the last 20 years, several approaches to antifungal discovery have been explored. The traditional approach seeks, first, to identify active compounds from large compound libraries using a panel of fungal pathogens in standardised assays when possible. In the genetic, genomic, or bioinformatics approach, the objective is, initially, to identify broadly represented targets in fungal pathogens and non-pathogens [18]. In this "target-centric" genomic approach, up-front genetic, bioinformatics, and biochemical target prioritisation is performed and, subsequently, an in vitro-based screening of individual targets is achieved. However, an exceedingly high rate of failure has been observed when applying this approach [19]. Additionally, not all bioactive compounds act through a target-specific mechanism of action (MoA). Various compounds act non-selectively as alkylating agents, intercalators, detergents, etc. Therefore, an integrated approach has been recently proposed for antimicrobial lead discovery that is rooted in empirical whole-cell screening for small molecules with intrinsic bioactivity whose MoA may be determined using a variety of forward or reverse genomic platforms to identify and, subsequently, validate their target [20]. In this "compound-centric" strategy, it is proposed to use existing genetic methods to evaluate the therapeutic effect of inactivating the target (both in vitro and in vivo). These methods often use the principles of genetic interaction, relying on the idea of genetic modifiers (enhancers or suppressors) to generate target hypotheses. Direct biochemical methods or computational inference have also been used for target identification. In many cases, however, a combination of approaches may be required to fully characterise on-target and off-target effects, and understand the mechanisms of small-molecule actions [21].

Recently, micro- and nanoscale approaches have been introduced in the field of antifungal drug discovery. In this paper, microfluidic approaches for antifungal screening and antifungal susceptibility testing (AFST), nanosensor development for AFST, and antifungal nanoparticles are reviewed.

\section{Emerging Fungal Diseases and Antifungal Drugs}

The epidemiology of invasive fungal infection is evolving [22-25]. A growing population of immunosuppressed patients have been diagnosed with invasive fungal infections. The epidemiology of candida infections has shifted over the last decade [26]. Non-albicans Candida species, with a reduced susceptibility to antifungals, are becoming more and more responsible for invasive candidiasis [27]. Several species, such as Candida glabrata and C. krusei, which are less susceptible to azole antifungal therapy, are increasing in some settings. C. auris has emerged in hospitals as a global concern, since the strains demonstrated multidrug resistance. Trichosporon species infections are the second most common cause of fungaemia in patients with haematological malignant disease and they were the third most commonly isolated non-candida species from patients in the ARTEMIS Global Antifungal Surveillance Program [28]. These species show resistance to amphotericin and echinocandins. Rhodotorula species are emerging opportunistic yeasts that are responsible for catheter-related fungaemia and sepsis, and invasive infections, particularly in immunosuppressed or -compromised patients [24]. The incidence of infections with non-neoformans crytococci has increased over the past 40 years, especially in patients with advanced HIV infection or cancer who are undergoing transplant [29]. Since the 1990s, there have been a growing number of reports about Saccharomyces cerevisiae invasive infections and novel strains continue to be identified $[24,30,31]$. 
Aspergillus species have, historically, been one of the most common causative organisms associated with invasive mould diseases [32]. Aspergillus fumigatus species were responsible for most of infections. Recently, the epidemiology has changed towards non-A. fumigatus species and other moulds, such as Zygomycetes [33-36], Fusarium [37,38], and Scedosporium [38,39] species. This is due to the occurrence of azole resistant Aspergillus species [40,41].

Antifungal development is challenging, since, apart from the fungal cell wall, fungi are metabolically similar to mammalian cells and, therefore, offer few pathogen-specific targets [42]. As explained above, only three molecular classes that target three different fungal metabolic pathways are commonly used in clinical practice to treat, essentially, systemic fungal infections: Polyenes, azoles, and echinocandins (Table 1) [43]. The fluoropyrimidine analog 5-fluorocystosine is also used, but only in combination with amphotericin B.

Table 1. Overview of the mostly used antifungal agents, mechanism of action (MoA), and spectrum of activity [43-50].

\begin{tabular}{|c|c|c|c|}
\hline Class Compound & MoA & Spectrum of Activity & Comment \\
\hline \multicolumn{4}{|l|}{ Polyenes } \\
\hline Amphotericin B & $\begin{array}{l}\text { Selective binding to ergosterol } \\
\text { cause the formation of pores in } \\
\text { the membrane. }\end{array}$ & $\begin{array}{l}\text { Treatment of deep mycoses, } \\
\text { candidiasis, cryptococcosis, } \\
\text { histoplasmosis, blastomycosis, } \\
\text { paracoccodioidomycosis, } \\
\text { cocciodioidomycosis, aspergillosis, } \\
\text { extracutaneous sporotrichichosis, } \\
\text { and some cases of mucormycosis, } \\
\text { hyalohyphomycosis, and } \\
\text { phaeohyphomycosis, S. cerevisiae. }\end{array}$ & $\begin{array}{c}\text { Fungicidal, broad spectrum, } \\
\text { intravenous, little resistance } \\
\text { observed, significant nephrotoxicity, } \\
\text { indirectly affects action of } \\
\text { many drugs. }\end{array}$ \\
\hline Nystatin/Nyotran & $\begin{array}{l}\text { Selective binding to ergosterol } \\
\text { cause the formation of pores in } \\
\text { the membrane. }\end{array}$ & Candidiasis & $\begin{array}{l}\text { Nyotran is a liposomal formulation } \\
\text { of nystatin with lowered toxicity. }\end{array}$ \\
\hline \multicolumn{4}{|l|}{ Azoles } \\
\hline Fluconazole & $\begin{array}{l}\text { Selective inhibition of fungal } \\
\text { cytochrome P450-dependent } \\
\text { lanosterol-14- } \alpha \text {-demethylase. }\end{array}$ & $\begin{array}{l}\text { Candida immitis, C. neoformans, } \\
\text { Paracoccidioides brasiliensis; lower } \\
\text { activity against Aspergillus, } \\
\text { Fusarium, Scedosporium, Penicillium } \\
\text { species and other } \\
\text { filamentous fungi. }\end{array}$ & $\begin{array}{l}\text { Fluconazole resistant } C \text {. albicans and } \\
\text { non-albicans strains increasing. }\end{array}$ \\
\hline Itraconazole & $\begin{array}{l}\text { Selective inhibition of fungal } \\
\text { cytochrome P450-dependent } \\
\text { lanosterol-14- } \alpha \text {-demethylase. }\end{array}$ & $\begin{array}{l}\text { Most Candida species, } \\
\text { P. brasiliensis, H. capsulatum, } \\
\text { Blastomyces dermatitidis, } \\
\text { Aspergillus fumigatus, } A \text {. niger, } \\
\text { Penicillium marneffei. }\end{array}$ & $\begin{array}{l}\text { Better than fluconazole in the } \\
\text { treatment of cocciodioido-mycosis, } \\
\text { not reaching the central nervous } \\
\text { system; numerous drug interactions } \\
\text { due to inhibition of CYP 3A4. }\end{array}$ \\
\hline Tioconazole & $\begin{array}{l}\text { Selective inhibition of fungal } \\
\text { cytochrome P450-dependent } \\
\text { lanosterol-14- } \alpha \text {-demethylase. }\end{array}$ & $\begin{array}{l}\text { C. albicans, Trichophyton sp., } \\
\text { Epidermophyton } \mathrm{sp} .\end{array}$ & $\begin{array}{l}\text { Is an immidazole antifungal for } \\
\text { topical treatment of superficial } \\
\text { mycoses (ringworm, jock itch, } \\
\text { athlete's foot, tinea versicolor. }\end{array}$ \\
\hline
\end{tabular}


Table 1. Cont.

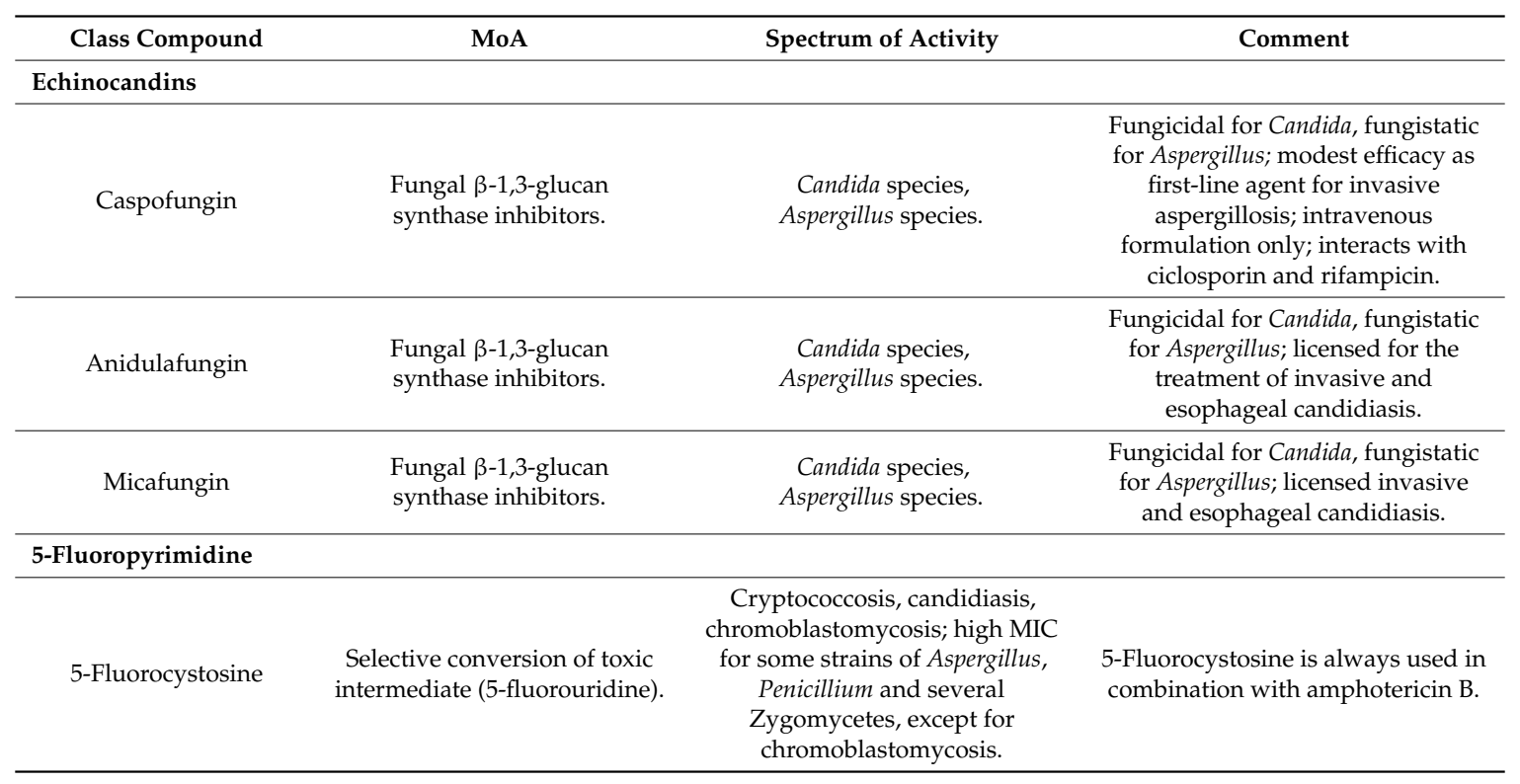

Recently, a lot of effort has also been made in analysing the antifungal action of natural compounds or natural bioactive compounds. The discovered natural antifungal derivatives or compounds derived from natural origins have been recently reviewed $[17,51]$. Some examples of these compounds include chitosan [52]; herbal compounds, such as thymol, carvacrol, eugenol, and menthol [53]; and extracts from plants, such as Hypericum carinatum [54], Stenachaenium megapotamicum [55], and Acca sellowiana [56].

\section{Omics-Based Antifungal Drug Discovery Approaches}

The traditional approach seeks, first, to identify active compounds (generally from large libraries of synthetic small molecules or natural products) that inhibit the growth of the fungus. The most commonly used assay to identify antifungal leads is liquid growth inhibition assay in which microbial growth is measured by optical density (OD) of the culture. These assays have some limitations, such as, sometimes, a poor correlation between growth and OD for fungi that grow as filaments, and these assays are unable to distinguish between molecules that inhibit growth (fungistatic) from those that kill the organism (fungicidal), a feature that is very important for the treatment of some fungi (e.g., Cryptococcus) [57]. Recently, cell viability screening assays based on other readouts have been developed. The most widely adopted approach is the use of the dyes, Alamar Blue and tetrazolium salt (XTT), as reporters for metabolic activity. These dyes are converted to fluorescent molecules when metabolised by viable molecules and can be used for high-throughput multiwell screening [58,59]. The dye, resazurin, was used to develop an assay for high-throughput screening of A. fumigatus [60]. An Alamar-Blue-based high-throughput protocol was devised to identify molecules with fungicidal activity against $C$. neoformans [61]. A second type of viability assay that was recently developed is based on the detection of extracellular adenylate kinase (AK) as a reporter of cell lysis [62]. AK is a conserved enzyme that has been used as a cytotoxicity reporter in mammalian cell culture assays and as a reporter of brewing yeast autolysis in the beverage industry [63].

Another approach is referred to as genetic, genomic, or bioinformatics in which the objective is, initially, to identify broadly represented targets in fungal pathogens and non-pathogens. The operational code for this strategy consists of three basic rules for identifying potential targets: (i) A bioinformatics-driven approach is used to identify pathogen-specific genes with the desired conservation and spectrum, and the absence of a human ortholog; (ii) genetic analyses are performed to confirm that loss-of-function mutations result in a nonviable growth phenotype and/or a nonvirulent 
phenotype under standard laboratory conditions and/or a nonvirulent phenotype in a relevant animal model of infection; and (iii) there should be some evidence, derived from sequence, structure, or biochemical information that the target is druggable [64]. This operational code was used to guide genomic and target-based antimicrobial discovery. Forward and reverse chemical-genetic methods have been used to identify the target of drug-like bioactive compounds and MoA. Target-based approaches have been pursued using high-throughput screening for inhibitor of enzymes and/or proteins that perform essential functions in microbes. Molecular target-based screening has provided mediocre to poor results in the field of anti-infective drug discovery, suggesting that cell-based screening for antimicrobials remains the most effective strategy [19]. Gene knockout microorganisms and small molecules with well-defined mechanisms can each be used to alter the functions of putative targets, uncovering dependencies on activity. Reverse chemical screens that exploit genome-wide collections of mutants have been employed to map susceptibility phenotypes to specific genes by systematically screening antimicrobial agents against a defined (ideally) comprehensive mutant collection [20]. Mating of laboratory and wild yeast strains can reveal patterns of small-molecule sensitivity with specific loci [65]. In another method, molecularly barcoded libraries of open reading frames have been used to detect small-molecule-resistant clones that are then identified by microarray analysis [66].

A proteomic profiling approach, based on two-dimensional difference gel electrophoresis and mass spectrometric identification of the proteins, has been used to predict the target protein of small molecules of interest [67]. It was demonstrated that this proteomic profiling system could discriminate small molecules by their mechanism of action. Omics methods have also been used successfully to identify the MoA of compounds that were discovered using traditional screening approaches. A key illustrative case is the discovery of the orotomide F901318 compound [68]. A combination of genetic and biochemical approaches revealed the target of F901318 in A. fumigatus, which was initially discovered in a high-throughput screen of compound libraries. It was found that F901318 acts via the inhibition of the pyrimidine biosynthesis enzyme, dihydroorotate dehydrogenase, in a fungal-specific manner.

Although only around 1100 of the 6000 genes of S. cerevisiae are essential under nutrient-rich growth conditions [69], almost all genes become essential in specific genetic backgrounds in which another non-essential gene has been deleted or otherwise attenuated, an effect termed synthetic lethality [70]. Genome-scale surveys suggest that over 200,000 binary synthetic lethal gene combinations dominate the yeast genetic landscape [71]. The genetic buffering phenomenon is also manifested as a phalanx of differential chemical-genetic interactions in the presence of sublethal doses of bioactive compounds [72]. These observations highlight the inherent redundancy of genetic networks and frame the problem of interdicting network functions with single agent therapeutics [73]. This genetic network organisation suggests that judicious combinations of small molecule inhibitors of both essential and non-essential targets may elicit additive or synergistic effects on cell growth $[74,75]$. Compounds that enhance the activity of known agents in yeasts have been identified by small molecule library screens [76-79]. Direct tests of synergistic compounds have successfully yielded combinations that are active against pathogenic fungi, such as the combination of fluconazole with chemical inhibitors (such as 17-AAG and 17-DMAG) of Hsp90 [80], calcineurin (such as miconazole, ketoconazole), or adenosine diphosphate (ADP) ribosylation factor (ARF) (such as brefeldin A [81], the antibiotic polymyxin B [78]), and compounds selected from an off-patent drugs library [79]. Combinatorial antifungal therapies have many advantages, including a decrease in the rate of selection of resistant strains, a lower required dosage of individual drugs, a decrease in host toxicity, and enhanced antifungal activity [82]. Syncretic combinations of drugs with improved antifungal properties can be readily identified in both model fungal species and highly pathogenic clinical isolates [83]. Additionally, it was shown that synergistic combinations usually yield enhanced selectivity without adverse side effects [84].

These, recently developed, omics-based approaches require expensive, automated, robotic screening platforms when applied in high throughput. Additionally, these platforms are usually 
based on multiwell screening, which has some limitations. As discussed in the next section, further improvements can be achieved by integrating these methods in microfluidic screening platforms.

\section{Micro- and Nanoscale Approaches}

\subsection{Microfluidic High-Throughput Antifungal Drug Discovery}

Growing cells in 96-, 384-, or 1536-well plates has miniaturised cell assays for drug discovery. These experiments with multiwell plates are typically integrated in a robotic analysis platform. Major drawbacks of robotic platforms are the expense of the instrumentation, the cost of experimental consumables, the systems are closed (no flow through of reagents or cell culture medium), and still a relatively high consumption of reagents compared to recent developed microfluidic chips. Additionally, as cell collections are growing, there is a need to further miniaturise the assays to increase the parallelism of analyses.

In microfluidic lab-on-a-chips, fluids are manipulated at the micrometer length scale [85]. Reducing the scale evidently reduces the reagent consumption and, consequently, the cost to perform assays, which becomes significant for high-throughput drug screening. The physics at micro/nano scale are exploited in microfluidic chip designs for drug discovery. Other physical phenomena dominate at this small length scale compared to the macroscale [86]. Fluid flow in microchannels is characterized by a low Reynolds number (a dimensional criterion that determines the relative importance of inertial and viscous effects). The dominant role of viscous forces results in laminar flow behavior and mass transport by diffusion between two adjacent fluids, resulting in the generation of stable concentration gradients [87]. Also, fast media and temperature changes can be obtained using the laminar flow [88]. Mass transport by diffusion becomes a fast mixing method when the length scale is reduced in small channels or wells. It has been demonstrated that, at these small length scales, time-resolved reactions have been conducted with millisecond resolution due to the extremely rapid diffusive mixing $[89,90]$. Surface tension plays an important role in the formation of small droplet emulsions in immiscible fluids in microfluidic channels [86]. Surface tension and viscous stresses destabilize the interface and create droplets when water is injected into a stream of oil at a T-junction or two perpendicular crossing microchannels [91]. Based on this principle, droplet-based microfluidic platforms have been developed to encapsulate and screen single cells [92].

Due to the ease of controlling the cellular environment, microfluidic technology has been used to perturb cellular physiology in screening arrays. Additionally, the cell number and density of a given area or volume can be controlled, which allows monitoring of a high spatial and temporal resolution and observation of the dynamic behavior of many cells $[93,94]$. Parallellisation of experimental conditions and automatization in microfluidic chips has resulted in designs for high-throughput cell screening [95], such as living cell microarrays [96-101]. Microfluidic parallelization and single-cell monitoring allows the measurement and averaging of parameters on hundreds of individual cells, compared to measuring parameters of a whole cell population. New insights can be obtained by observing single cells, such as the monitoring of certain classes of proteins, using fluorescently tagged proteins [102,103] and give information about the cell-to-cell variation in a heterogeneous microbial population [104-106]. Automation of microfluidic cell culture systems also leads to standardized manipulation and monitoring, which allows the perfect timing of protocols to characterize dynamic processes at high temporal resolution to be performed [94].

Cellular microarray platforms have been developed for high-throughput antifungal drug discovery based on the screening of nanoliter biofilms that are created in hydrogels (Table 2). Robotic printing is used to fabricate the cellular arrays. The formation of biofilms complicates antifungal therapy, since the ability of fungal cells to form biofilms is an important reason for the emergence of severe resistance to most clinically available antifungal agents [107-110]. A better understanding of fungal biofilms provides new opportunities for the development of urgently needed novel antifungal agents and strategies. 
Table 2. Examples of microfluidic platforms for high-throughput antifungal drug discovery.

\begin{tabular}{|c|c|c|c|c|}
\hline $\begin{array}{l}\text { High-Throughput } \\
\text { Technology }\end{array}$ & Application & Microorganism & Characteristics & References \\
\hline Cellular microarray & Antifungal biofilm screening & Candida albicans & $\begin{array}{l}\text { Cells robotically printed, } \\
768(48 \times 16 \text { array }) \text { cultures of } \\
50 \mathrm{~nL} \text { biofilms in collagen. }\end{array}$ & {$[111,112]$} \\
\hline Cellular microarray & Antifungal biofilm screening & C. albicans & $\begin{array}{c}\text { Cells robotically printed, } \\
1200(60 \times 20 \text { array }) \text { cultures of } \\
30 \mathrm{~nL} \text { biofilms in alginate. }\end{array}$ & [113] \\
\hline Cellular microarray & $\begin{array}{l}\text { Antibiotic and antifungal } \\
\text { biofilm screening }\end{array}$ & $\begin{array}{c}\text { C. albicans, } \\
\text { Staphylococcus aureus, } \\
\text { Pseudomonas aeruginosa }\end{array}$ & $\begin{array}{l}\text { Robotically printing of mono- } \\
\text { and polymicrobial biofilms, } \\
576(48 \times 12 \text { array }) \text { cultures of } \\
30 \mathrm{~nL} \text { biofilms in alginate. }\end{array}$ & [114] \\
\hline Droplet microfluidics & Antifungal drug screening & Phytophthora sojae & $\begin{array}{l}\text { The plant pathogen spores and } \\
\text { the drug were encapsulated in } \\
\text { liquid droplets. Phenotypic } \\
\text { responses to the drug at } \\
\text { different concentrations were } \\
\text { microscopically quantified. }\end{array}$ & [115] \\
\hline
\end{tabular}

\subsection{Microfluidics for Antifungal Susceptibility Testing}

Resistant microbial infections are becoming a major threat to public health, causing increasing mortality worldwide. The fast emergence of multiresistant pathogens is caused by extensive, and sometimes unnecessary, use of antimicrobials and the lack of interest in developing new variants. The cost of antimicrobial resistance (AMR) is projected to increase significantly as some models predict a rise in global casualties from the present figure of one million to 10 million in 2050 [116]. A survey of antimicrobial susceptibility test (AST) methods available demonstrated a need for new approaches that would enable rapid, inexpensive, and sensitive tests that can quickly provide physicians with antibiotic profiles [117]. A quick diagnostic method is necessary to prescribe a patient that is infected by a life-threatening microbe with an effective antimicrobial [118]. AST is widely applied to determine antimicrobial resistance profiles of the microbial isolates and to help in the selection of an antimicrobial treatment option [117,119-121]. Currently, AST is usually not performed in the clinic, but in a clinical microbiology lab, which necessitates transportation of the patient samples [122]. Current susceptibility tests, that are based on cell culturing of the pathogen, can take several days (especially for slow growing microbes) and extends the time to make the correct diagnosis and decisions for appropriate and effective antimicrobial therapy. This leads to increased patient mortality and the use of broad-spectrum antimicrobials that promote resistance [120]. To survive this evolutionary war against microbial pathogens, we must pursue technologies that can rapidly perform AST to enable personalized therapies (narrow-spectrum antimicrobial administration) at the earliest possible treatment stage [122].

Standard antifungal susceptibility (AFST) methods rely on measuring fungal growth in the presence of antifungals over a few days. The broth microdilution (BMD) is the standard method for the evaluation of susceptibility to antifungal agents in Candida species [123-126]. Standardized micro-dilution-based procedures by the Clinical and Laboratory Standards Institute (CLSI) and the European Committee on Antibiotic Susceptibility Testing (EUCAST) are universally accepted for performing AFST [127]. However, these procedures are complex, time-consuming, and not intended for routine use.

Commercially available tests, such as Sensititre YeastOne (broth microdilution method), Etest (agar-based disk diffusion method), and the fully automated Vitek 2 (broth microdilution method) yeast susceptibility system, all easy-to-use modifications from CLSI/EUCAST reference methods, are widely used for testing antifungal susceptibility of relevant Candida and Aspergillus species [10]. New diagnostic approaches based on emerging technologies, such as flow cytometry, MALDI-TOF mass spectroscopy, and isothermal microcalorimetry, have been developed to expand, and potentially improve, the capability of the clinical microbiology laboratory to yield AFST results [126]. Flow cytometry is used to determine the effect of an antifungal compound by measuring changes in the 
viability of fungal cells that are fluorescently labeled [128,129]. A simple and rapid AFST assay based on MALDI-TOF was developed [130]. This approach facilitated the discrimination of the susceptible and resistant isolates of C. albicans after a 3-h incubation in the presence of "breakpoint" level drug concentrations of the echinocandin caspofungin (CSF). A microcalorimetry-based AFST assay has been developed for real-time susceptibility testing of Aspergillus spp. [131]. The method is based on measuring changes in growth-related heat production in the presence of the antifungal compound.

Semi-automated susceptibility systems (such as VITEK and MicroScan) decrease the turn-around-time and operator touch-time (culture and colony isolation are still required) compared to traditional culture-based methods, but can add significant cost to the tests [132]. The fastest test still requires $9 \mathrm{~h}$ and, therefore, these semi-automated systems do not provide information in time to influence initial treatment decisions [133,134].

Since microfluidics promises several advantages over existing macro-scale methods, several microfluidic platforms that can perform rapid antimicrobial susceptibility tests have been developed during the last years (Table 3) [132,135]. The recent development of microfluidic platforms was mostly focused on devices for antibiotics susceptibility testing and much less on antifungals susceptibility testing, although the same designs could, usually, be used for both (e.g., see [136,137]). Most systems rely on microscopic transmission or fluorescence observation of cells to quantify the effect of the antimicrobial on the cell growth or viability. The microorganisms are confined to a small volume (wells, channels, chambers, or droplets). In many systems, the cells are immobilized in a hydrogel, such as agarose or alginate (Table 3) (Figure 1).

Table 3. Examples of microfluidic platforms for antimicrobial susceptibility testing.

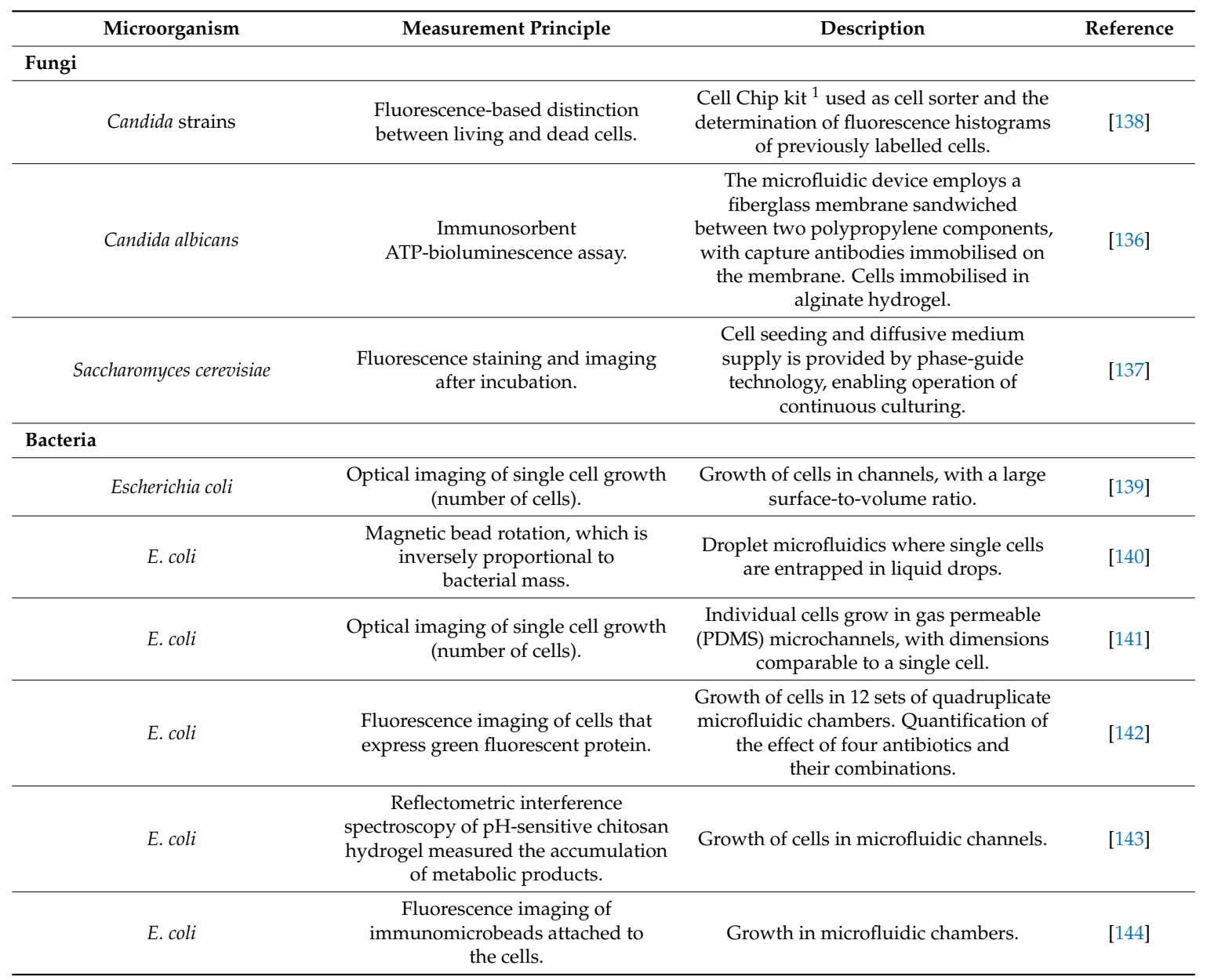


Table 3. Cont

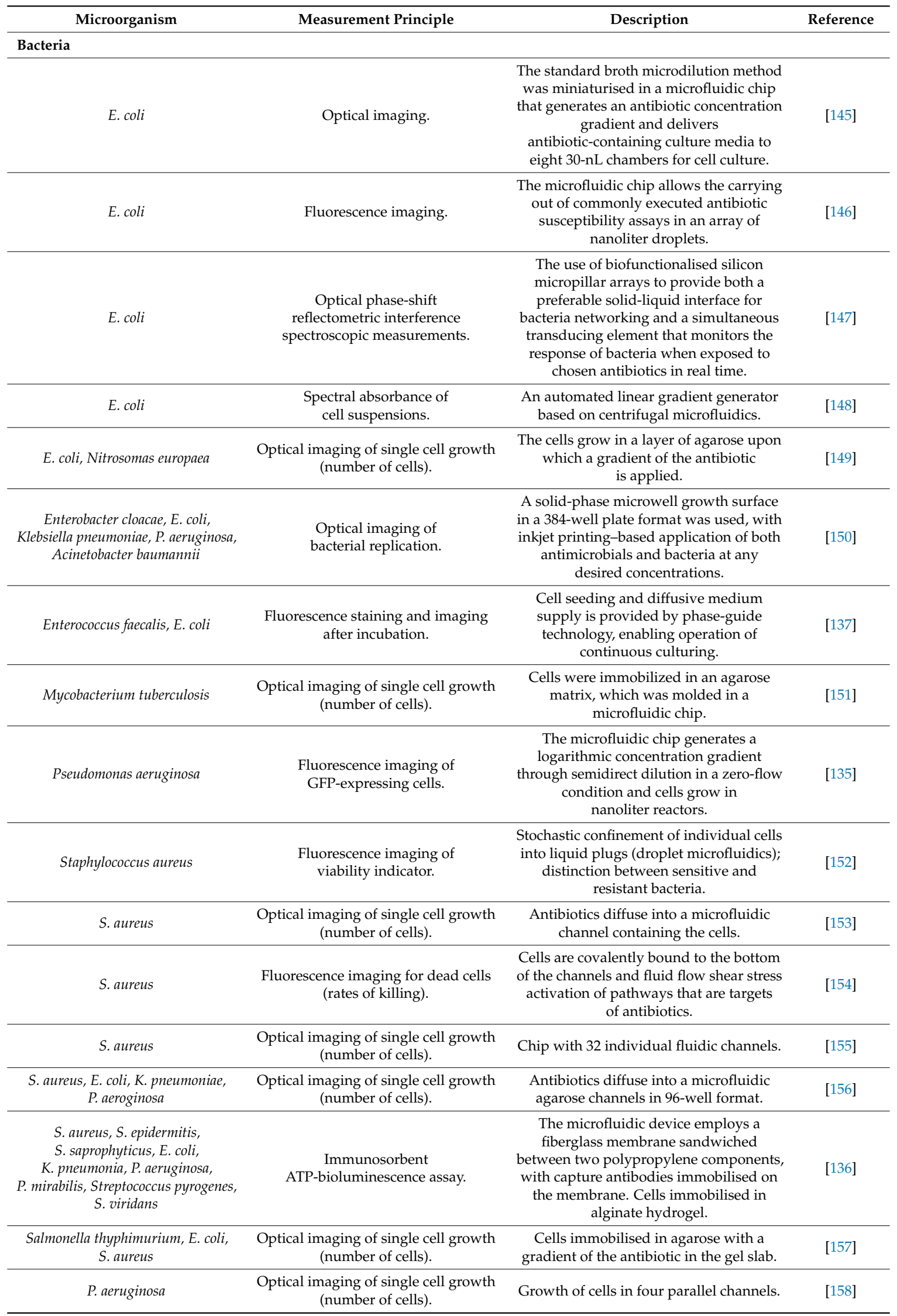



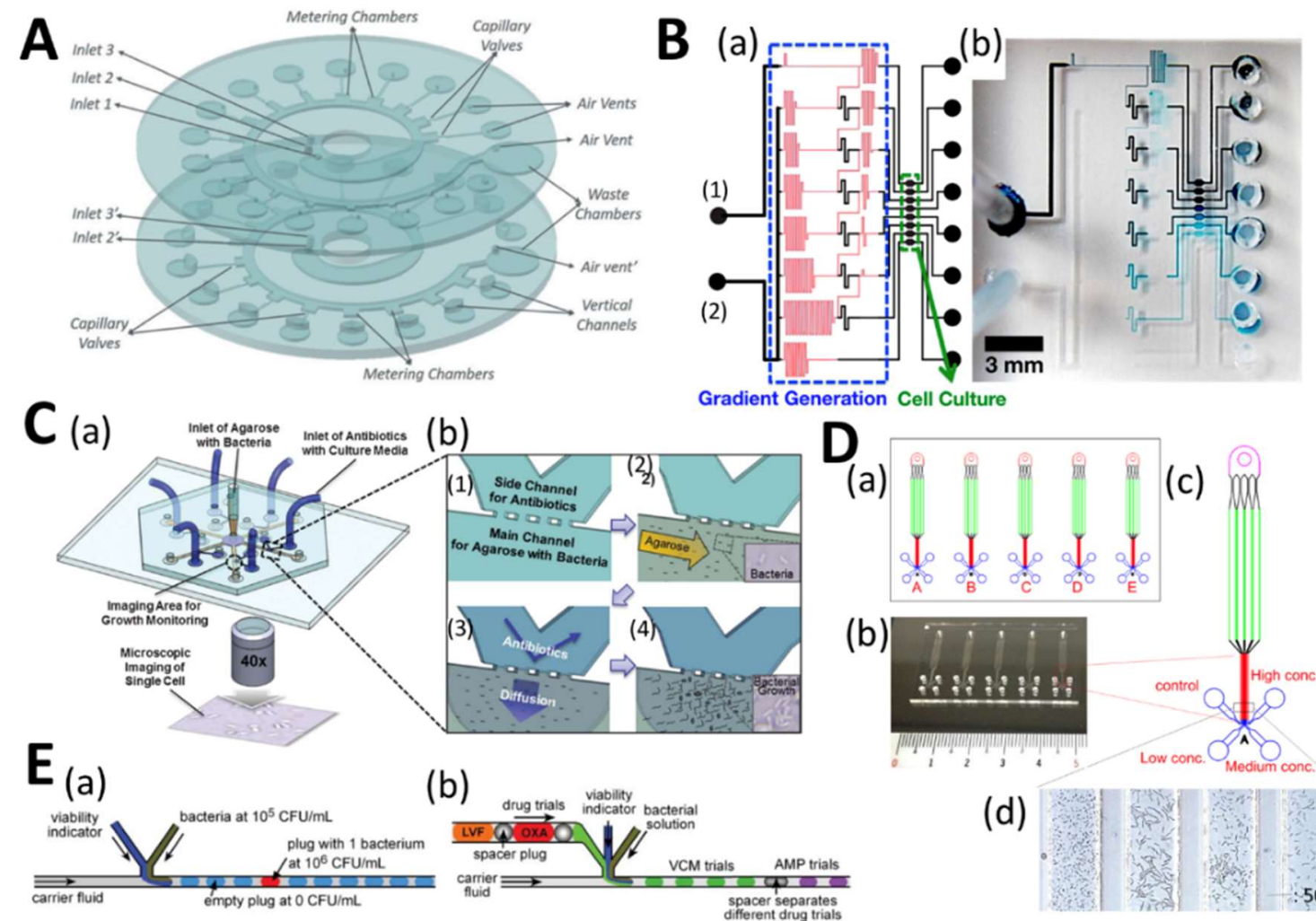

(b)

Gradient Generation Cell Culture
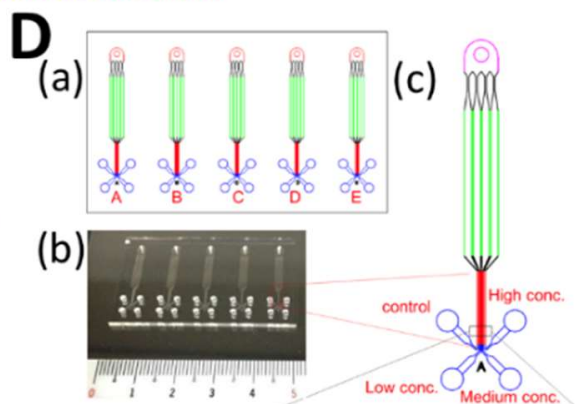

(b)
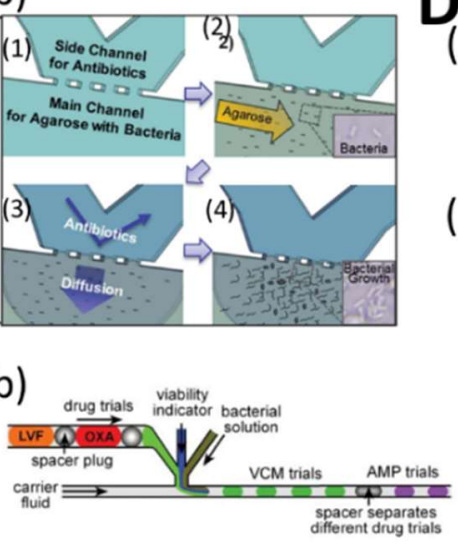

(d)

Figure 1. (A) An automated linear concentration gradient generator based on centrifugal microfluidics for antibiotic susceptibility testing (AST). The operation is based on the use of multi-layered microfluidics in which individual fluidic samples to be mixed together are stored and metered in their respective layers before, finally, being transferred to a mixing chamber. Reprinted with permission

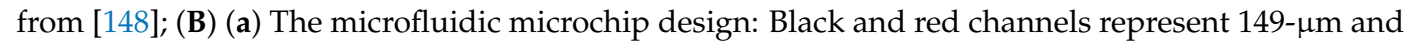
4- $\mu \mathrm{m}$ tall features, respectively; (b) A photograph of the fabricated PDMS chip. Blue food dye solution and water were injected to upper (1) and lower (2) inlet ports. (a) Reprinted with permission from [145]; (C) Schematic diagram of the AST process for the microfluidic agarose channel (MAC) system. (a) The MAC chip was fabricated with PDMS on glass. An agarose-bacteria mixture solution was injected into the center of the chip, which flowed synchronously into the six main channels. Each interface between the agarose with the bacteria and antibiotic solutions was monitored microscopically to analyse bacterial cell growth. (b) (1) The empty channel before AST. (2) The bacteria were mixed with agarose and then injected into the main channels. (3) A sharp interface was generated due to the anchors and then liquid medium with different concentrations of antibiotic. (4) Time-lapse microscopic observation of a bacterial cell. Reprinted with permission from [153]; (D) The structure of the AST microfluidic device for MIC determination of five drugs. (a) Design. (b) Actual image. (c) Precise structure of one set of fluids. (d) Microscopic image of Pseudomonas aeruginosa grown in the presence of piperacillin. Reprinted with permission from [158]; (E) Stochastic confinement of bacteria into plugs. (a) Schematic drawing illustrates the increase in cell density, resulting from the stochastic confinement of an individual bacterium in a nanoliter-sized plug. (b) Screening of many antibiotics against the same bacterial sample. Antibiotics: Ampicillin (AMP), levofloxacin (LVF), vancomycin (VCN), and oxacillin (OXA). Reprinted with permission from [152]. 


\subsection{Nanomotion Analysis for Evaluating Antifungal Suscessibility}

Recently, very new sensitive sensor technologies based on microcantilevers have been developed [159-161]. Nanomechanical oscillators are being used for the detection of very small masses [162,163], for measuring buoyant mass, and determining the "instantaneous" growth rates of individual cells [164] for the quantitative time-resolved membrane protein (vancomycin)—ligand (mucopeptides) on cantilever arrays with $10 \mathrm{nM}$ sensitivity and at clinically relevant concentrations in blood serum [165]. Cantilever nanosensors have been used to measure mass differences in the pico- to femtogram ranges in air [166] and liquid [167,168]. Many of the available systems are limited by the need to perform the measurements in air or in a humid environment [161].

Microcantilevers have been explored as nanosensors for living cell studies, since they offer many advantages, such as being highly sensitive, selective, label-free, performed in real time, and provide in situ detection capabilities [169]. Single cell detection and monitoring on the cantilever sensor has been reported for S. cerevisiae cells [164,170,171], E. coli [164,171,172], Bacillus subtilis [164,172], Enterococcus faecalis [171], HeLa cells [173], mouse lymphoblasts [164], and human lung carcinoma and mouse lymphocytic leukemia cells [171,174], and mouse and human T cells [171]. Cell growth detection has been demonstrated by monitoring resonance frequency changes of cantilevers as the mass increases from immobilized S. cerevisiae and fungal A. niger spores on the surface of the cantilevers in humid air [175]. S. cerevisiae cells were deposited onto the cantilever surface and its bending as a function of time and corresponded to the yeast growth behaviour [169]. Recently, serial microfluidic mass resonator arrays were used to measure single-cell growth of yeast, bacterial and mammalian cells in liquid and a higher throughput [171].

Recently, a nanomechanical detector, that can be used to assess the effects of chemicals on living organisms in a timeframe of minutes, was developed. In this technique, the living microorganisms are adsorbed to the surface of a nanomechanical sensor, i.e., an AFM cantilever, and its fluctuations are measured as a function of time (Figure 2). This approach requires only a few minutes without cell growth, since the decrease in cell activity in the presence of the antimicrobial is measured. Moreover, it is a label-free technique. These are major advantages compared to current methods. Antimicrobials can be introduced in the measuring chamber, allowing a rapid identification of the antimicrobial to which the microorganism is susceptible. The sensor position detection is similar to the one used in Atomic Force Microscopy (AFM): A laser beam is focused onto the sensor (cantilever) and ends its path onto a multisegment photodiode. Numerous proof-of-concept experiments have been performed involving several species of bacteria and fungi. By comparing this method with the traditional techniques in double-blind experiments, a success rate close to $90 \%$ could be achieved [176]. The variation of the nanovibration signal is directly proportional to the metabolic activity of the microbial cell. It allowed estimating with unpreceded speed (15 min per ampicillin dose), the minimum inhibitory (MIC) and bactericidal concentrations (MBC) for the effect of the antibiotic ampicillin on E. coli [177]. The high sensitivity of the nanosensor allowed differentiation between bacteriostatic (kanamycin) and bactericidal (ampicillin) effects when exposed to a resistant E. coli. The high sensitivity of the nanosensor made it possible to differentiate between bacteriostatic and bactericidal effects. Recently, this method was successfully applied to blood culture pellets to determine the antibiotic susceptibility against agents of bloodstream infection [178]. AFM-nanomotion detection (NMD) has also been applied for AFST, where the effect of a low $(10 \mu \mathrm{g} / \mathrm{mL})$ and high $(40 \mu \mathrm{g} / \mathrm{mL})$ caspofungin concentration on C. albicans was evaluated [179]. It was recently demonstrated that AFM-cantilever NMD is so sensitive that single-cell activities of $S$. cerevisiae cells could be detected [179], and even cell cycle progression could be observed [180]. 

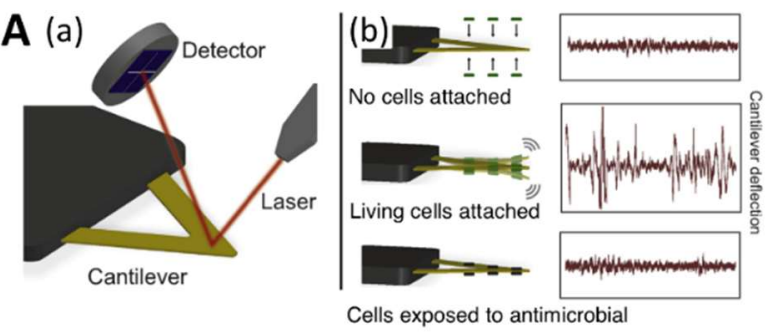

B

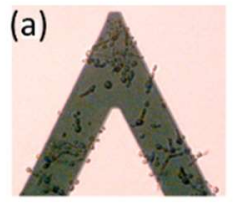

(b)

(c)

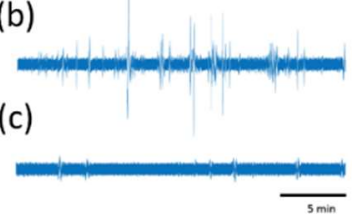

Figure 2. (A) Outline of experimental setup and description of experiments. (a) Schematics of nanomotion detector setup with a cantilever sensor; laser beam is focused on the surface of the sensor and reflection is used to monitor movements of the cantilever. (b) Representation of a typical nanomotion susceptibility test. When microorganisms are not attached to the sensor, fluctuations are driven only by thermal motion and are relatively low. After attachment of living cells, fluctuations are linked to their metabolic activity and are high. Finally, after exposure to an antimicrobial drug, the cells are nonviable and fluctuations return to low levels. Reprinted with permission from [178].

(B) (a) C. albicans deposited onto a cantilever. (b) Reprinted with permission from [161].

\subsection{Antifungal Nanoparticles}

Due to the development of antimicrobial resistance, pharmaceutical companies and researchers are searching for new antimicrobial agents. Nanoscale materials have emerged as novel antimicrobial agents, owing to their high surface area to volume ratio and their unique chemical and physical properties [181,182]. By definition, nanoparticles are structures that have dimensions in the 1-100 nm [183]. Silver nanoparticles (Ag-NPs) are one of the most commonly used nanomaterials in consumer and medical products because of their antimicrobial activity $[184,185]$. It is increasingly used in a variety of both medical and consumer products, resulting in an increase in human exposure [183,186]. A large number of in vitro studies indicate that Ag-NPs are also toxic to mammalian cells derived from the skin, liver, lung, brain, vascular system, reproductive organs, and the immune system. Although significant progress has been achieved on the elucidation of the antimicrobial mechanism of silver nanoparticles, the exact mechanism of action is still not completely known [187]. It has been demonstrated that non-cytotoxic doses of Ag-NPs could induce genes that are associated with cell cycle progression [188,189] and apoptosis in human hepatoma cells [189]. DNA damage by Ag-NPs in mammalian cells has also been reported [188,190]. The mechanisms for Ag-NP induced toxicity include the effects of this particle on cell membranes, mitochondria, and genetic material. It has been recently demonstrated that bacteria (E. coli, P. aeruginosa) can also develop resistance to silver nanoparticles after repeated exposure [191]. The biosynthesis of silver nanoparticles is now considered to be the most environmentally friendly and cost-effective method [185]. It can be achieved using a variety of organisms, such as by the fungi, A. flavus [185], A. terreus [192], Arthroderma fulvum [193], Penicillium fellutanum [194], and P. expansum [192].

Other nanostructures have been discovered that also show antifungal activity. It was demonstrated that cationic terephthalamide-bisurea molecules showed excellent microbial selectivity, with minimal host toxicity [195]. The terephthalamide-bisurea recognition motif facilitated spontaneous supramolecular self-assembly, with the formation of fibres in water. Antifungal activity against clinically isolated, drug-sensitive, and drug-resistant Cryptococcus neoformans strains was observed. These antifungal agents showed effectively dispersed $C$. albicans biofilms and excellent in vivo biocompatibility. Homogeneously dispersed copper nanoparticles (originating from n-Cu sepiolite fibres) in soda-lime glass powder showed high antibacterial properties against gram-positive (Micrococcus luteus) and gram-negative bacteria (E. coli), and antifungal (Issatchenkia orientalis) activity [196]. The observed high activity of the n-Cu glass powder was explained by the inhibitory synergistic effect of the $\mathrm{Ca}^{2+}$ lixiviated from the glass on the growth of the cells, since n-Cu sepiolite had no significant antifungal activity. Another approach of obtaining nanoparticles with antifungal activity is to immobilize, covalently, the antifungal amphotericin into nanomaterials, such as silica 
nanoparticles [197]. These antifungal nanoparticle conjugates demonstrated fungicidal activity against several strains of Candida sp., mainly by contact. In addition, they could be reused for up to five cycles without losing their activity. The results showed that the antifungal nanoparticle conjugates were more fungistatic and fungicidal than $10 \mathrm{~nm}$ colloidal silver.

\section{Conclusions}

Fungal infections continue to appear as the population of people with an altered immune system increases. An impaired immune system arises due to medical intervention, immunosuppressive diseases, or malnutrition. The infections become life-threatening for systemic infections. The therapeutic options for invasive fungal infections are limited, since a very limited number of structural classes of drug compounds are available and some demonstrate significant limitations. The discovery of new antifungals is mostly achieved by the screening of natural or synthetic/semisynthetic chemical compounds [16,17]. Using the genomics approach, substantial progress has been made in antifungal drug development for a multitude of potential drug targets [198] and inhibitors [199,200]. Recent advances that could support and refine the antifungal pipeline were focused on elucidating fungal pathways, targets, and mechanisms of action that could lead to new antifungal therapies; antifungal compounds and immune strategies currently in development that could become new antifungal therapies; improved formulations of existing compounds; and the repurposing of drugs approved for other indications and could show potential antifungal activity [16]

Surely, there is a need for novel antifungal discovery approaches. The current antifungal tools that are available to tackle the invasive fungal epidemic occurring in clinics and hospitals have improved, but are still inadequate for use in all patient groups [16]. Recently, micro- and nanoscale approaches have been introduced in antifungal drug discovery. It has become increasingly clear in trends in antimicrobial drug discovery that microfluidic approaches will have an increasing role. The capability of manipulating fluids, flexibility on geometries and materials, manipulation of a large number of cells simultaneously and independently, and ease of integrating numerous analytical standard operations and large-scale integration makes microfluidic devices a versatile tool for antifungal drugs. One of the future challenges lies in the construction of extended cell microarrays, or single-cell droplet arrays, and integration in the microfluidic chip [100], since the recently developed bioinformatics approach for antifungal discovery could be further improved by integrating these methods in a microfluidic screening platform. Living cell arraying methods, based on closed microchambers arrays in microfluidic bioreactors, could increase throughput significantly compared to classical multiwell-plate cell assays, with significantly reduced amounts spent on expensive test reagents, cells, and chemical compounds, and without the need for expensive robotic multiwell-plate screening facilities.

Significant progress has been made in the development of microfluidic platforms for antimicrobial susceptibility testing (AST). Recent efforts are focused on the development of AFST methods that are independent of cell growth and can provide susceptibility results in a very short time frame. These methods rely on measuring the cell death in the presence of the antifungal. A promising technique is the AFM-based nanomotion detection, which can give an answer about the susceptibility in a few minutes. Further parallelization of this method is required to introduce it in the clinic.

Nanoscale materials have emerged as novel antimicrobial agents. One of the most extensively studied nanoparticles are silver nanoparticles and this is for their antifungal, but also antibacterial and antiviral, activities. In minute concentrations, it was found not to be toxic to humans and microorganisms [185]. Further research should focus on a better understanding the toxicity and determining the exact mechanism of the interaction between nanoparticles and cells.

Acknowledgments: The Belgian Federal Science Policy Office (Belspo) and the European Space Agency (ESA) PRODEX program supported this work. The Research Council of the Vrije Universiteit Brussel (Belgium) and the University of Ghent (Belgium) are acknowledged to support the Alliance Research Group VUB-UGent 
NanoMicrobiology (NAMI), and the International Joint Research Group (IJRG) VUB-EPFL BioNanotechnology \& NanoMedicine (NANO).

Conflicts of Interest: The author declares no conflict of interest.

\section{References}

1. Vos, T.; Flaxman, A.D.; Naghavi, M.; Lozano, R.; Michaud, C.; Ezzati, M.; Shibuya, K.; Salomon, J.A.; Abdalla, S.; Aboyans, V.; et al. Years lived with disability (YLDs) for 1160 sequelae of 289 diseases and injuries 1990-2010: A systematic analysis for the Global Burden of Disease Study 2010. Lancet 2012, 380, $2163-2196$. [CrossRef]

2. Brown, G.D.; Denning, D.W.; Levitz, S.M. Tackling human fungal infections. Science 2012, 336, 647. [CrossRef] [PubMed]

3. Richardson, M.D. Changing patterns and trends in systemic fungal infections. J. Antimicrob. Chemother. 2005, 56 (Suppl. 1), i5-i11. [CrossRef] [PubMed]

4. Huttunen, R.; Syrjänen, J. Obesity and the risk and outcome of infection. Int. J. Obes. 2013, 37, $333-340$. [CrossRef] [PubMed]

5. Rytter, M.J.; Kolte, L.; Briend, A.; Friis, H.; Christensen, V.B. The immune system in children with malnutrition-A systematic review. PLoS ONE 2014, 9, e105017. [CrossRef] [PubMed]

6. Ibrahim, M.K.; Zambruni, M.; Melby, C.L.; Melby, P.C. Impact of childhood malnutrition on host defense and infection. Clin. Microbiol. Rev. 2017, 30, 919-971. [CrossRef] [PubMed]

7. Denning, D.W.; Bromley, M.J. Infectious Disease. How to bolster the antifungal pipeline. Science 2015, 347, 1414-1416. [CrossRef] [PubMed]

8. Lemke, A.; Kiderlen, A.F.; Kayser, O. Amphotericin B. Appl. Microbiol. Biotechnol. 2005, 68, $151-162$. [CrossRef] [PubMed]

9. Bellmann, R. Pharmacodynamics and pharmacokinetics of antifungals for treatment of invasive aspergillosis. Curr. Pharm. Des. 2013, 19, 3629-3647. [CrossRef] [PubMed]

10. Pfaller, M.A. Antifungal drug resistance: Mechanisms, epidemiology, and consequences for treatment. Am. J. Med. 2012, 125 (Suppl. 1), S3-S13. [CrossRef] [PubMed]

11. Pianalto, K.M.; Alspaugh, J.A. New Horizons in Antifungal Therapy. J. Fungi. 2016, 2, 26. [CrossRef] [PubMed]

12. Nivoix, Y.; Ubeaud-Sequier, G.; Engel, P.; Levêque, D.; Herbrecht, R. Drug-drug interactions of triazole antifungal agents in multimorbid patients and implications for patient care. Curr. Drug. Metab. 2009, 10, 395-409. [CrossRef] [PubMed]

13. Lewis, R.E. Current concepts in antifungal pharmacology. Mayo Clin. Proc. 2011, 86, 805-817. [CrossRef] [PubMed]

14. Campoy, S.; Adrio, J.L. Antifungals. Mayo Clin. Proc. 2017, 133, 86-96. [CrossRef] [PubMed]

15. McCarthy, M.W.; Walsh, T.J. Drugs currently under investigation for the treatment of invasive candidiasis. Expert. Opin. Investig. Drugs 2017, 26, 825-831. [CrossRef] [PubMed]

16. Perfect, J.R. The antifungal pipeline: A reality check. Nat. Rev. Drug Discov. 2017, 16, 603-616. [CrossRef] [PubMed]

17. Fuentefria, A.M.; Pippi, B.; Dalla Lana, D.F.; Donato, K.K.; de Andrade, S.F. Antifungals discovery: An insight into new strategies to combat antifungal resistance. Lett. Appl. Microbiol. 2018, 66, 2-13. [CrossRef] [PubMed]

18. Weig, M.; Brown, A.J. Genomics and the development of new diagnostics and anti-Candida drugs. Trends Microbiol. 2007, 15, 310-317. [CrossRef] [PubMed]

19. Payne, D.J.; Gwynn, M.N.; Holmes, D.J.; Pompliano, D.L. Drugs for bad bugs: Confronting the challenges of antibacterial discovery. Nat. Rev. Drug Discov. 2007, 6, 29-40. [CrossRef] [PubMed]

20. Roemer, T.; Boone, C. Systems-level antimicrobial drug and drug synergy discovery. Nat. Chem. Biol. 2013, 9, 222-231. [CrossRef] [PubMed]

21. Schenone, M.; Dančík, V.; Wagner, B.K.; Clemons, P.A. Target identification and mechanism of action in chemical biology and drug discovery. Nat. Chem. Biol. 2013, 9, 232-240. [CrossRef] [PubMed]

22. Nucci, M.; Marr, K.A. Emerging fungal diseases. Clin. Infect. Dis. 2005, 41, 521-526. [CrossRef] [PubMed] 
23. Castón-Osorio, J.J.; Rivero, A.; Torre-Cisneros, J. Epidemiology of invasive fungal infection. Int. J. Antimicrob. Agents 2008, 32 (Suppl. 2), S103-S109. [CrossRef]

24. Miceli, M.H.; Díaz, J.A.; Lee, S.A. Emerging opportunistic yeast infections. Lancet Infect. Dis. 2011, 11, $142-151$. [CrossRef]

25. Galimberti, R.; Torre, A.C.; Baztán, M.C.; Rodriguez-Chiappetta, F. Emerging systemic fungal infections. Clin. Dermatol. 2012, 30, 633-650. [CrossRef] [PubMed]

26. Enoch, D.A.; Yang, H.; Aliyu, S.H.; Micallef, C. The Changing Epidemiology of Invasive Fungal Infections. In Human Fungal Pathogen Identification. Methods in Molecular Biology; Lion, T., Ed.; Humana Press: New York, NY, USA, 2017; Volume 1508, pp. 17-65. ISBN 978-1-4939-6513-7.

27. Schwartz, I.S.; Patterson, T.F. The Emerging Threat of antifungal resistance in transplant infectious diseases. Curr. Infect. Dis. Rep. 2018, 20, 2. [CrossRef] [PubMed]

28. Pfaller, M.A.; Diekema, D.J.; Gibbs, D.L.; Newell, V.A.; Ellis, D.; Tullio, V.; Rodloff, A.; Fu, W.; Ling, T.A. Global Antifungal Surveillance Group. Results from the ARTEMIS DIS Global Antifungal Surveillance Study, 1997 to 2007: A 10.5-year analysis of susceptibilities of Candida Species to fluconazole and voriconazole as determined by CLSI standardized disk diffusion. J. Clin. Microbiol. 2010, 48, 1366-1377. [CrossRef] [PubMed]

29. Khawcharoenporn, T.; Apisarnthanarak, A.; Mundy, L.M. Non-neoformans cryptococcal infections: A systematic review. Infection 2007, 35, 51-58. [CrossRef] [PubMed]

30. Enache-Angoulvant, A.; Hennequin, C. Invasive Saccharomyces infection: A comprehensive review. Clin. Infect. Dis. 2005, 41, 1559-1568. [CrossRef] [PubMed]

31. Anoop, V.; Rotaru, S.; Shwed, P.S.; Tayabali, A.F.; Arvanitakis, G. Review of current methods for characterizing virulence and pathogenicity potential of industrial Saccharomyces cerevisiae strains towards humans. FEMS Yeast Res. 2015, 15, fov057-2. [CrossRef] [PubMed]

32. Lass-Flörl, C.; Cuenca-Estrella, M. Changes in the epidemiological landscape of invasive mould infections and disease. J. Antimicrob. Chemother. 2017, 72 (Suppl. 1), i5-i11. [CrossRef] [PubMed]

33. Ribes, J.A.; Vanover-Sams, C.L.; Baker, D.J. Zygomycetes in human disease. Clin. Microbiol. Rev. 2000, 13, 236-301. [CrossRef] [PubMed]

34. Kontoyiannis, D.P.; Marr, K.A.; Park, B.J.; Alexander, B.D.; Anaissie, E.J.; Walsh, T.J.; Ito, J.; Andes, D.R.; Baddley, J.W.; Brown, J.M.; et al. Prospective surveillance for invasive fungal infections in hematopoietic stem cell transplant recipients, 2001-2006: Overview of the Transplant-Associated Infection Surveillance Network (TRANSNET) Database. Clin. Infect. Dis. 2010, 50, 1091-1100. [CrossRef] [PubMed]

35. Roilides, E.; Zaoutis, T.E.; Walsh, T.J. Invasive zygomycosis in neonates and children. Clin. Microbiol. Infect. 2009, 15 (Suppl. 5), 50-54. [CrossRef] [PubMed]

36. Lanternier, F.; Lortholary, O. Zygomycosis and diabetes mellitus. Clin. Microbiol. Infect. 2009, 15 (Suppl. 5), 21-25. [CrossRef] [PubMed]

37. Nucci, M.; Anaissie, E. Fusarium infections in immunocompromised patients. Clin. Microbiol. Rev. 2007, 20, 695-704. [CrossRef] [PubMed]

38. Tortorano, A.M.; Richardson, M.; Roilides, E.; Diepeningen, A.V.; Caira, M.; Munoz, P.; Johnson, E.; Meletiadis, J.; Pana, Z.D.; Lackner, M.; et al. ESCMID \& ECMM Joint Guidelines on Diagnosis and Management of Hyalohyphomycosis: Fusarium spp., Scedosporium spp., and others. Clin. Microbiol. Infect. 2014, 20 (Suppl. 3), 27-46. [PubMed]

39. Guarro, J.; Kantarcioglu, A.S.; Horré, R.; Luis Rodriguez-Tudela, J.; Cuenca Estrella, M.; Berenguer, J.; Sybren De Hoog, G. Scedosporium apiospermum: Changing clinical spectrum of a therapy-refractory opportunist. Med. Mycol. 2006, 44, 295-327. [CrossRef] [PubMed]

40. Montesinos, I.; Dodemont, M.; Lagrou, K.; Jacobs, F.; Etienne, I.; Denis, O. New case of azole-resistant Aspergillus fumigatus due to TR46/Y121F/T289A mutation in Belgium. J. Antimicrob. Chemother. 2014, 69, 3439-3440. [CrossRef] [PubMed]

41. Buil, J.B.; Meis, J.F.; Melchers, W.J.; Verweij, P.E. Are the TR46/Y121F/T289A Mutations in Azole-Resistant Aspergillosis Patient Acquired or Environmental? Antimicrob. Agents Chemother. 2016, 60, 3259-3260. [CrossRef] [PubMed]

42. Ostrosky-Zeichner, L.; Casadevall, A.; Galgiani, J.N.; Odds, F.C.; Rex, J.H. An insight into the antifungal pipeline: Selected new molecules and beyond. Nat. Rev. Drug Discov. 2010, 9, 719-727. [CrossRef] [PubMed]

43. Vandeputte, P.; Ferrari, S.; Coste, A.T. Antifungal resistance and new strategies to control fungal infections. Int. J. Microbiol. 2012, 2012, 713687. [CrossRef] [PubMed] 
44. Ballard, S.A.; Lodola, A.; Tarbit, M.H. A comparative study of 1-substituted imidazole and 1,2,4-triazole antifungal compounds as inhibitors of testosterone hydroxylations catalysed by mouse hepatic microsomal cytochromes P-450. Biochem. Pharmacol. 1988, 37, 4643-4651. [CrossRef]

45. DiDomenico, B. Novel antifungal drugs. Curr. Opin. Microbiol. 1999, 2, 509-515. [CrossRef]

46. Arévalo, M.P.; Carrillo-Muñoz, A.J.; Salgado, J.; Cardenes, D.; Brió, S.; Quindós, G.; Espinel-Ingroff, A. Antifungal activity of the echinocandin anidulafungin (VER002, LY-303366) against yeast pathogens: A comparative study with M27-A microdilution method. J. Antimicrob. Chemother. 2003, 51, 163-166. [CrossRef] [PubMed]

47. Mukherjee, P.K.; Sheehan, D.; Puzniak, L.; Schlamm, H.; Ghannoum, M.A. Echinocandins: Are they all the same? J. Chemother. 2011, 23, 319-325. [CrossRef] [PubMed]

48. Firooz, A.; Nafisi, S.; Maibach, H.I. Novel drug delivery strategies for improving econazole antifungal action. Int. J. Pharm. 2015, 495, 599-607. [CrossRef] [PubMed]

49. Denning, D.W.; Hope, W.W. Therapy for fungal diseases: Opportunities and priorities. Trends Microbiol. 2010, 18, 195-204. [CrossRef] [PubMed]

50. Terra, L.; Abreu, P.A.; Teixeira, V.L.; Paixão, I.C.; Pereira, R.; Leal, B.; Lourenço, A.L.; Rampelotto, P.H.; Castro, H.C. Mycoses and Antifungals: Reviewing the basis of a current problem that still is a biotechnological target for marine products. Front. Mar. Sci. 2014, 1, 12. [CrossRef]

51. Vengurlekar, S.; Sharma, R.; Trivedi, P. Efficacy of some natural compounds as antifungal agents. Pharmacogn. Rev. 2012, 6, 91-99. [CrossRef] [PubMed]

52. Lopez-Moya, F.; Colom-Valiente, M.F.; Martinez-Peinado, P.; Martinez-Lopez, J.E.; Puelles, E.; Sempere-Ortells, J.M.; Lopez-Llorca, L.V. Carbon and nitrogen limitation increase chitosan antifungal activity in Neurospora crassa and fungal human pathogens. Fungal. Biol. 2015, 119, 154-169. [CrossRef] [PubMed]

53. Abbaszadeh, S.; Sharifzadeh, A.; Shokri, H.; Khosravi, A.R.; Abbaszadeh, A. Antifungal efficacy of thymol, carvacrol, eugenol and menthol as alternative agents to control the growth of food-relevant fungi. J. Mycol. Med. 2014, 24, e51-e56. [CrossRef] [PubMed]

54. Barros, F.M.C.; Pippi, B.; Dresch, R.R.; Dauber, B.; Luciano, S.C.; Apel, M.A.; Fuentefria, A.M.; Von Poser, G.L. Antifungal and antichemotactic activities and quantification of phenolic compounds in lipophilic extracts of Hypericum spp. native to South Brazil. Ind. Crops Prod. 2013, 44, 294-299. [CrossRef]

55. Danielli, L.J.; Dos Reis, M.; Bianchini, M.; Camargo, G.S.; Bordignon, S.A.L.; Guerreiro, I.K.; Fuentefria, A.; Apel, M.A. Antidermatophytic activity of volatile oil and nanoemulsion of Stenachaenium megapotamicum (Spreng.) Baker. Ind. Crops Prod. 2013, 50, 23-28. [CrossRef]

56. Machado, G.R.; Pippi, B.; Dalla Lana, D.F.; Amaral, A.P.S.; Teixeira, M.L.; De Souza, K.C.B.; Fuentefria, A.M. Reversal of fluconazole resistance induced by a synergistic effect with Acca sellowiana in Candida glabrata strains. Pharm. Biol. 2016, 54, 2410-2419. [CrossRef] [PubMed]

57. Bicanic, T.; Muzoora, C.; Brouwer, A.E.; Meintjes, G.; Longley, N.; Taseera, K.; Rebe, K.; Loyse, A.; Jarvis, J.; Bekker, L.G.; et al. Independent association between rate of clearance of infection and clinical outcome of HIV-associated cryptococcal meningitis: Analysis of a combined cohort of 262 patients. Clin. Infect. Dis. 2009, 49, 702-709. [CrossRef] [PubMed]

58. Pierce, C.G.; Uppuluri, P.; Tristan, A.R.; Wormley, F.L., Jr.; Mowat, E.; Ramage, G.; Lopez-Ribot, J.L. A simple and reproducible 96-well plate-based method for the formation of fungal biofilms and its application to antifungal susceptibility testing. Nat. Protoc. 2008, 3, 1494-1500. [CrossRef] [PubMed]

59. LaFleur, M.D.; Lucumi, E.; Napper, A.D.; Diamond, S.L.; Lewis, K.N. Novel high-throughput screen against Candida albicans identifies antifungal potentiators and agents effective against biofilms. J. Antimicrob. Chemother. 2011, 66, 820-826. [CrossRef] [PubMed]

60. Monteiro, M.C.; de la Cruz, M.; Cantizani, J.; Moreno, C.; Tormo, J.R.; Mellado, E.; De Lucas, J.R.; Asensio, F.; Valiante, V.; Brakhage, A.A.; et al. A new approach to drug discovery: High-throughput screening of microbial natural extracts against Aspergillus fumigatus using resazurin. J. Biomol. Screen 2012, 17, 542-549. [CrossRef] [PubMed]

61. Rabjohns, J.L.A.; Park, Y.D.; Dehdashti, J.; Henderson, C.; Zelazny, A.; Metallo, S.J.; Zheng, W.; Williamson, P.R. A high-throughput screening assay for fungicidal compounds against Cryptococcus neoformans. J. Biomol. Screen 2014, 19, 270-277. [CrossRef] [PubMed] 
62. DiDone, L.; Scrimale, T.; Baxter, B.K.; Krysan, D.J. A high-throughput assay of yeast cell lysis for drug discovery and genetic analysis. Nat. Protoc. 2010, 5, 1107-1114. [CrossRef] [PubMed]

63. Cameron-Clarke, A.; Hulse, G.A.; Clifton, L.; Cantrell, I.C. The Use of Adenylate Kinase Measurement to Determine Causes of Lysis in Lager Yeast. J Am. Soc. Brew. Chem. 2003, 61, 152-156. [CrossRef]

64. Roemer, T.; Krysan, D.J. Antifungal drug development: Challenges, unmet clinical needs, and new approaches. Cold Spring Harb. Perspect. Med. 2014, 4, A019703. [CrossRef] [PubMed]

65. Perlstein, E.O.; Ruderfer, D.M.; Roberts, D.C.; Schreiber, S.L.; Kruglyak, L. Genetic basis of individual differences in the response to small-molecule drugs in yeast. Nat. Genet. 2007, 39, 496-502. [CrossRef] [PubMed]

66. Pierce, S.E.; Fung, E.L.; Jaramillo, D.F.; Chu, A.M.; Davis, R.W.; Nislow, C.; Giaever, G. A unique and universal molecular barcode array. Nat. Methods 2006, 3, 601-603. [CrossRef] [PubMed]

67. Muroi, M.; Kazami, S.; Noda, K.; Kondo, H.; Takayama, H.; Kawatani, M.; Usui, T.; Osada, H. Application of proteomic profiling based on 2D-DIGE for classification of compounds according to the mechanism of action. Chem. Biol. 2010, 17, 460-470. [CrossRef] [PubMed]

68. Oliver, J.D.; Sibley, G.E.; Beckmann, N.; Dobb, K.S.; Slater, M.J.; McEntee, L.; du Pré, S.; Livermore, J.; Bromley, M.J.; Wiederhold, N.P.; et al. F901318 represents a novel class of antifungal drug that inhibits dihydroorotate dehydrogenase. Proc. Natl. Acad. Sci. USA 2016, 133, 12809-12814. [CrossRef] [PubMed]

69. Winzeler, E.A.; Shoemaker, D.D.; Astromoff, A.; Liang, H.; Anderson, K.; Andre, B.; Bangham, R.; Benito, R.; Boeke, J.D.; Bussey, H.; et al. Functional characterization of the S. cerevisiae genome by gene deletion and parallel analysis. Science 1999, 285, 901-906. [CrossRef] [PubMed]

70. Tong, A.H.; Evangelista, M.; Parsons, A.B.; Xu, H.; Bader, G.D.; Pagé, N.; Robinson, M.; Raghibizadeh, S.; Hogue, C.W.; Bussey, H.; et al. Systematic genetic analysis with ordered arrays of yeast deletion mutants. Science 2001, 294, 2364-2368. [CrossRef] [PubMed]

71. Costanzo, M.; Baryshnikova, A.; Bellay, J.; Kim, Y.; Spear, E.D.; Sevier, C.S.; Ding, H.; Koh, J.L.; Toufighi, K.; Mostafavi, S.; et al. The genetic landscape of a cell. Science 2010, 327, 425-431. [CrossRef] [PubMed]

72. Hillenmeyer, M.E.; Fung, E.; Wildenhain, J.; Pierce, S.E.; Hoon, S.; Lee, W.; Proctor, M.; St Onge, R.P.; Tyers, M.; Koller, D.; et al. The chemical genomic portrait of yeast: Uncovering a phenotype for all genes. Science 2008, 320, 362-365. [CrossRef] [PubMed]

73. Hopkins, A.L. Network pharmacology: The next paradigm in drug discovery. Nat. Chem. Biol. 2008, 4, 682-690. [CrossRef] [PubMed]

74. Fitzgerald, J.B.; Schoeberl, B.; Nielsen, U.B.; Sorger, P.K. Systems biology and combination therapy in the quest for clinical efficacy. Nat. Chem. Biol. 2006, 2, 458-466. [CrossRef] [PubMed]

75. Lehár, J.; Stockwell, B.R.; Giaever, G.; Nislow, C. Combination chemical genetics. Nat. Chem. Biol. 2008, 4, 674-681. [CrossRef] [PubMed]

76. Borisy, A.A.; Elliott, P.J.; Hurst, N.W.; Lee, M.S.; Lehar, J.; Price, E.R.; Serbedzija, G.; Zimmermann, G.R.; Foley, M.A.; Stockwell, B.R.; et al. Systematic discovery of multicomponent therapeutics. Proc. Natl. Acad. Sci. USA 2003, 100, 7977-7982. [CrossRef] [PubMed]

77. Zhang, L.; Yan, K.; Zhang, Y.; Huang, R.; Bian, J.; Zheng, C.; Sun, H.; Chen, Z.; Sun, N.; An, R.; et al. High-throughput synergy screening identifies microbial metabolites as combination agents for the treatment of fungal infections. Proc. Natl. Acad. Sci. USA 2007, 104, 4606-4611. [CrossRef] [PubMed]

78. Zhai, B.; Zhou, H.; Yang, L.; Zhang, J.; Jung, K.; Giam, C.Z.; Xiang, X.; Lin, X. Polymyxin B, in combination with fluconazole, exerts a potent fungicidal effect. J. Antimicrob. Chemother. 2010, 65, 931-938. [CrossRef] [PubMed]

79. Spitzer, M.; Griffiths, E.; Blakely, K.M.; Wildenhain, J.; Ejim, L.; Rossi, L.; De Pascale, G.; Curak, J.; Brown, E.; Tyers, M.; et al. Cross-species discovery of syncretic drug combinations that potentiate the antifungal fluconazole. Mol. Syst. Biol. 2011, 7, 499. [CrossRef] [PubMed]

80. Cowen, L.E.; Singh, S.D.; Köhler, J.R.; Collins, C.; Zaas, A.K.; Schell, W.A.; Aziz, H.; Mylonakis, E.; Perfect, J.R.; Whitesell, L.; Lindquist, S. Harnessing Hsp90 function as a powerful, broadly effective therapeutic strategy for fungal infectious disease. Proc. Natl. Acad. Sci. USA 2009, 106, 2818-2823. [CrossRef] [PubMed]

81. Epp, E.; Vanier, G.; Harcus, D.; Lee, A.Y.; Jansen, G.; Hallett, M.; Sheppard, D.C.; Thomas, D.Y.; Munro, C.A.; Mullick, A.; et al. Reverse genetics in Candida albicans predicts ARF cycling is essential for drug resistance and virulence. PLoS Pathog. 2010, 6, e1000753. [CrossRef] [PubMed] 
82. Sharom, J.R.; Bellows, D.S.; Tyers, M. From large networks to small molecules. Curr. Opin. Chem. Biol. 2004, 8, 81-90. [CrossRef] [PubMed]

83. Jansen, G.; Lee, A.Y.; Epp, E.; Fredette, A.; Surprenant, J.; Harcus, D.; Scott, M.; Tan, E.; Nishimura, T.; Whiteway, M.; et al. Chemogenomic profiling predicts antifungal synergies. Mol. Syst. Biol. 2009, 5, 338. [CrossRef] [PubMed]

84. Lehár, J.; Krueger, A.S.; Avery, W.; Heilbut, A.M.; Johansen, L.M.; Price, E.R.; Rickles, R.J.; Short, G.F., 3rd; Staunton, J.E.; Jin, X.; et al. Synergistic drug combinations tend to improve therapeutically relevant selectivity. Nat. Biotechnol. 2009, 27, 659-666. [CrossRef]

85. Whitesides, G.M. The origins and the future of microfluidics. Nature 2006, 442, 368-373. [CrossRef] [PubMed]

86. Squires, T.M.; Quake, S.R. Microfluidics: Fluid physics at the nanoliter scale. Rev. Mod. Phys. 2005, 77, 977-1026. [CrossRef]

87. Dertinger, S.K.W.; Chiu, D.T.; Jeon, N.L.; Whitesides, G.M. Generation of Gradients Having Complex Shapes Using Microfluidic Networks. Anal. Chem. 2001, 73, 1240-1246. [CrossRef]

88. Sackmann, E.K.; Fulton, A.L.; Beebe, D.J. The present and future role of microfluidics in biomedical research. Nature 2014, 507, 181-189. [CrossRef] [PubMed]

89. Knight, J.B.; Vishwanath, A.; Brody, J.P.; Austin, R.H. Hydrodynamic focusing on a silicon chip: Mixing nanoliters in microseconds. Phys. Rev. Lett. 1998, 80, 3863-3866. [CrossRef]

90. Pollack, L.; Tate, M.W.; Finnefrock, A.C.; Kalidas, C.; Trotter, S.; Darnton, N.C.; Lurio, L.; Austin, R.H.; Batt, C.A.; Gruner, S.M.; et al. Time resolved collapse of a folding protein observed with small angle X-ray scattering. Phys. Rev. Lett. 2001, 86, 4962-4965. [CrossRef] [PubMed]

91. Wen, N.; Zhao, Z.; Fan, B.; Chen, D.; Men, D.; Wang, J.; Chen, J. Development of Droplet Microfluidics Enabling High-Throughput Single-Cell Analysis. Molecules 2016, 21, 881. [CrossRef] [PubMed]

92. Clausell-Tormos, J.; Lieber, D.; Baret, J.C.; El-Harrak, A.; Miller, O.J.; Frenz, L.; Blouwolff, J.; Humphry, K.J.; Köster, S.; Duan, H.; et al. Droplet-based microfluidic platforms for the encapsulation and screening of Mammalian cells and multicellular organisms. Chem. Biol. 2008, 15, 427-437. [CrossRef] [PubMed]

93. Kim, D.; Wu, X.; Young, A.T.; Haynes, C.L. Microfluidics-based in vivo mimetic systems for the study of cellular biology. Acc. Chem. Res. 2014, 47, 1165-1173. [CrossRef] [PubMed]

94. Mehling, M.; Tay, S. Microfluidic cell culture. Curr. Opin. Biotechnol. 2014, 25, 95-102. [CrossRef] [PubMed]

95. Velve-Casquillas, G.; le Berre, M.; Piel, M.; Tran, P.T. Microfluidic tools for cell biological research. Nano Today 2010, 5, 28-47. [CrossRef] [PubMed]

96. Castel, D.; Pitaval, A.; Debily, M.A.; Gidrol, X. Cell microarrays in drug discovery. Drug Discov. Today 2006, 11, 616-622. [CrossRef] [PubMed]

97. Chen, D.S.; Davis, M.M. Molecular and functional analysis using live cell microarrays. Curr. Opin. Chem. Biol. 2006, 10, 28-34. [CrossRef] [PubMed]

98. Yarmush, M.L.; King, K.R. Living-cell microarrays. Annu. Rev. Biomed. Eng. 2009, 11, 235-257. [CrossRef] [PubMed]

99. Willaert, R.; Sahli, H. On-chip living-cell microarrays for network biology. In Bioinformatics-Trends and Methodologies; Mahdavi, M.A., Ed.; InTech-Open Access: PublisherRejeka, Croatia, 2011; pp. 609-630. ISBN 978-953-307-282-1.

100. Willaert, R.G.; Goossens, K. Microfluidic bioreactors for cellular microarrays. Fermentation 2015, 1, 38-78. [CrossRef]

101. Jonczyk, R.; Kurth, T.; Lavrentieva, A.; Walter, J.G.; Scheper, T.; Stahl, F. Living cell microarrays: An overview of concepts. Microarrays 2016, 5, 11. [CrossRef] [PubMed]

102. Charvin, G.; Cross, F.R.; Siggia, E.D. Forced periodic expression of G1 cyclins phase-locks the budding yeast cell cycle. Proc. Natl. Acad. Sci. USA 2009, 106, 6632-6637. [CrossRef] [PubMed]

103. Bean, J.M.; Siggia, E.D.; Cross, F.R. Coherence and timing of cell cycle start examined at single-cell resolution. Mol. Cell 2006, 21, 3-14. [CrossRef] [PubMed]

104. Lidstrom, M.E.; Konopka, M.C. The role of physiological heterogeneity in microbial population behavior. Nat. Chem. Biol. 2010, 6, 705-712. [CrossRef] [PubMed]

105. Martins, B.M.; Locke, J.C. Microbial individuality: How single-cell heterogeneity enables population level strategies. Curr. Opin. Microbiol. 2015, 24, 104-112. [CrossRef] [PubMed]

106. Rosenthal, K.; Oehling, V.; Dusny, C.; Schmid, A. Beyond the bulk: Disclosing the life of single microbial cells. FEMS Microbiol. Rev. 2017, 41, 751-780. [CrossRef] [PubMed] 
107. Pierce, C.G.; Srinivasan, A.; Uppuluri, P.; Ramasubramanian, A.K.; López-Ribot, J.L. Antifungal therapy with an emphasis on biofilms. Curr. Opin. Pharmacol. 2013, 13, 726-730. [CrossRef] [PubMed]

108. Borghi, E.; Borgo, F.; Morace, G. Fungal Biofilms: Update on Resistance. Adv. Exp. Med. Biol. 2016, 931, 37-47. [CrossRef] [PubMed]

109. Koo, H.; Allan, R.N.; Howlin, R.P.; Stoodley, P.; Hall-Stoodley, L. Targeting microbial biofilms: Current and prospective therapeutic strategies. Nat. Rev. Microbiol. 2017, 15, 740-755. [CrossRef] [PubMed]

110. Wu, S.; Wang, Y.; Liu, N.; Dong, G.; Sheng, C. Tackling Fungal Resistance by Biofilm Inhibitors. J. Med. Chem. 2017, 60, 2193-2211. [CrossRef] [PubMed]

111. Srinivasan, A.; Uppuluri, P.; Lopez-Ribot, J.; Ramasubramanian, A.K. Development of a high-throughput Candida albicans biofilm chip. PLoS ONE 2011, 6, e19036. [CrossRef] [PubMed]

112. Srinivasan, A.; Lopez-Ribot, J.L.; Ramasubramanian, A.K. Candida albicans biofilm chip (CaBChip) for high-throughput antifungal drug screening. J. Vis. Exp. 2012, 18, e3845. [CrossRef]

113. Srinivasan, A.; Leung, K.P.; Lopez-Ribot, J.L.; Ramasubramanian, A.K. High-throughput nano-biofilm microarray for antifungal drug discovery. MBio 2013, 4, E00331-13. [CrossRef] [PubMed]

114. Srinivasan, A.; Torres, N.S.; Leung, K.P.; Lopez-Ribot, J.L.; Ramasubramanian, A.K. nBioChip, a Lab-on-a-Chip Platform of Mono- and Polymicrobial Biofilms for High-Throughput Downstream Applications. mSphere 2017, 2. [CrossRef] [PubMed]

115. Yang, H.; Bharracharyya, M.K.; Dong, L. Plant Pathogen Spores Grow in Microfluidic Droplets: A High-Throughput Approach to Antifungal Drug Screening. In Proceedings of the IEEE Conference paper Transducers' 11, Beijing, China, 5-9 June 2011.

116. Michael, C.A.; Dominey-Howes, D.; Labbate, M. The antimicrobial resistance crisis: Causes, consequences, and management. Front. Public Health 2014, 2, 145. [CrossRef] [PubMed]

117. Jorgensen, J.H.; Ferraro, M.J. Antimicrobial susceptibility testing: A review of general principles and contemporary practices. Clin. Infect. Dis. 2009, 49, 1749-1755. [CrossRef] [PubMed]

118. Barenfanger, J.; Drake, C.; Kacich, G. Clinical and financial benefits of rapid bacterial identification and antimicrobial susceptibility testing. J. Clin. Microbiol. 1999, 37, 1415-1418. [PubMed]

119. Arikan, S. Current status of antifungal susceptibility testing methods. Med. Mycol. 2007, 45, 569-587. [CrossRef] [PubMed]

120. Daniels, R. Surviving the first hours in sepsis: Getting the basics right (an intensivist's perspective). J. Antimicrob. Chemother. 2011, 66, 11-23. [CrossRef] [PubMed]

121. Alcazar-Fuoli, L.; Mellado, E. Current status of antifungal resistance and its impact on clinical practice. Br. J. Haematol. 2014, 166, 471-484. [CrossRef] [PubMed]

122. Syal, K.; Mo, M.; Yu, H.; Iriya, R.; Jing, W.; Guodong, S.; Wang, S.; Grys, T.E.; Haydel, S.E.; Tao, N. Current and emerging techniques for antibiotic susceptibility tests. Theranostics 2017, 7, 1795-1805. [CrossRef] [PubMed]

123. Clinical and Laboratory Standards Institute. Reference Method for Broth Dilution Antifungal Susceptibility Testing of Yeasts. Approved Standard M27-A3, 3rd ed.; CLSI: Wayne, PA, USA, 2008.

124. Arendrup, M.C.; Cuenca-Estrella, M.; Lass-Florl, C.; Hope, W.; Eucast, A. EUCAST technical note on the EUCAST definitive document EDef 7.2: Method for the determination of broth dilution minimum inhibitory concentrations of antifungal agents for yeasts EDef 7.2 (EUCAST-AFST). Clin. Microbiol. Infect. 2012, 18, E246-E247. [CrossRef] [PubMed]

125. Pulido, M.R.; García-Quintanilla, M.; Martín-Peña, R.; Cisneros, J.M.; McConnell, M.J. Progress on the development of rapid methods for antimicrobial susceptibility testing. J. Antimicrob. Chemother. 2013, 68, 2710-2717. [CrossRef] [PubMed]

126. Posteraro, B.; Torelli, R.; De Carolis, E.; Posteraro, P.; Sanguinetti, M. Antifungal susceptibility testing: Current role from the clinical laboratory perspective. Mediterr. J. Hematol. Infect. Dis. 2014, 6, e2014030. [CrossRef] [PubMed]

127. Subcommittee on Antifungal Susceptibility Testing of the ESCMID European Committee for Antimicrobial Susceptibility Testing. EUCAST Technical Note on the method for the determination of broth dilution minimum inhibitory concentrations of antifungal agents for conidia-forming moulds. Clin. Microbiol. Infect. 2008, 14, 982-984.

128. Vale-Silva, L.A.; Buchta, V. Antifungal susceptibility testing by flow cytometry: Is it the future? Mycoses 2006, 49, 261-273. [CrossRef] [PubMed] 
129. Vale-Silva, L.A.; Pinto, P.; Lopes, V.; Ramos, H.; Pinto, E. Comparison of the Etest and a rapid flow cytometry-based method with the reference CLSI broth microdilution protocol M27-A3 for the echinocandin susceptibility testing of Candida spp. Eur. J. Clin. Microbiol. Infect. Dis. 2012, 31, 941-946. [CrossRef] [PubMed]

130. Vella, A.; De Carolis, E.; Vaccaro, L.; Posteraro, P.; Perlin, D.S.; Kostrzewa, M.; Posteraro, B.; Sanguinetti, M. Rapid antifungal susceptibility testing by matrix-assisted laser desorption ionization time of flight mass spectrometry analysis. J. Clin. Microbiol. 2013, 51, 2964-2969. [CrossRef] [PubMed]

131. Furustrand Tafin, U.; Clauss, M.; Hauser, P.M.; Bille, J.; Meis, J.F.; Trampuz, A. Isothermal microcalorimetry: A novel method for real- time determination of antifungal susceptibility of Aspergillus species. Clin. Microbiol. Infect. 2012, 18, E241-E245. [CrossRef] [PubMed]

132. Campbell, J.; McBeth, C.; Kalashnikov, M.; Boardman, A.K.; Sharon, A.; Sauer-Budge, A.F. Microfluidic advances in phenotypic antibiotic susceptibility testing. Biomed. Microdevices 2016, 18, 103. [CrossRef] [PubMed]

133. Mittman, S.A.; Huard, R.C.; Della-Latta, P.; Whittier, S. Comparison of BD phoenix to vitek 2, microscan MICroSTREP, and Etest for antimicrobial susceptibility testing of Streptococcus pneumoniae. J. Clin. Microbiol. 2009, 47, 3557-3561. [CrossRef] [PubMed]

134. Chatzigeorgiou, K.S.; Sergentanis, T.N.; Tsiodras, S.; Hamodrakas, S.J.; Bagos, P.G. Phoenix 100 versus Vitek 2 in the identification of gram-positive and gram-negative bacteria: A comprehensive meta-analysis. J. Clin. Microbiol. 2011, 49, 3284-3291. [CrossRef] [PubMed]

135. Dai, J.; Suh, S.J.; Hamon, M.; Hong, J.W. Determination of antibiotic EC50 using a zero-flow microfluidic chip based growth phenotype assay. Biotechnol. J. 2015, 10, 1783-1791. [CrossRef] [PubMed]

136. Dong, T.; Zhao, X. Rapid identification and susceptibility testing of uropathogenic microbes via immunosorbent ATP-bioluminescence assay on a microfluidic simulator for antibiotic therapy. Anal. Chem. 2015, 87, 2410-2418. [CrossRef] [PubMed]

137. Puchberger-Enengl, D.; van den Driesche, S.; Krutzler, C.; Keplinger, F.; Vellekoop, M.J. Hydrogel-based microfluidic incubator for microorganism cultivation and analyses. Biomicrofluidics 2015, 9, 014127. [CrossRef] [PubMed]

138. Bouquet, O.; Kocsis, B.; Kilár, F.; Lóránd, T.; Kustos, I. Amphotericin B and fluconazole susceptibility of Candida species determined by cell-chip technology. Mycoses 2012, 55, e90-e96. [CrossRef] [PubMed]

139. Chen, C.H.; Lu, Y.; Sin, M.L.; Mach, K.E.; Zhang, D.D.; Gau, V.; Liao, J.C.; Wong, P.K. Antimicrobial susceptibility testing using high surface-to-volume ratio microchannels. Anal. Chem. 2010, 82, 1012-1019. [CrossRef] [PubMed]

140. Sinn, I.; Kinnunen, P.; Albertson, T.; McNaughton, B.H.; Newton, D.W.; Burns, M.A.; Kopelman, R. Asynchronous magnetic bead rotation (AMBR) biosensor in microfluidic droplets for rapid bacterial growth and susceptibility measurements. Lab Chip 2011, 11, 2604-2611. [CrossRef] [PubMed]

141. Lu, Y.; Gao, J.; Zhang, D.D.; Gau, V.; Liao, J.C.; Wong, P.K. Single cell antimicrobial susceptibility testing by confined microchannels and electrokinetic loading. Anal. Chem. 2013, 85, 3971-3976. [CrossRef] [PubMed]

142. Mohan, R.; Mukherjee, A.; Sevgen, S.E.; Sanpitakseree, C.; Lee, J.; Schroeder, C.M.; Kenis, P.J. A multiplexed microfluidic platform for rapid antibiotic susceptibility testing. Biosens. Bioelectron. 2013, 49, 118-125. [CrossRef] [PubMed]

143. Tang, Y.; Zhen, L.; Liu, J.; Wu, J. Rapid antibiotic susceptibility testing in a microfluidic pH sensor. Anal. Chem. 2013, 85, 2787-2794. [CrossRef] [PubMed]

144. He, J.; Mu, X.; Guo, Z.; Hao, H.; Zhang, C.; Zhao, Z.; Wang, Q. A novel microbead-based microfluidic device for rapid bacterial identification and antibiotic susceptibility testing. Eur. J. Clin. Microbiol. Infect. Dis. 2014, 33, 2223-2230. [CrossRef] [PubMed]

145. Kim, S.C.; Cestellos-Blanco, S.; Inoue, K.; Zare, R.N. Miniaturized Antimicrobial Susceptibility Test by Combining Concentration Gradient Generation and Rapid Cell Culturing. Antibiotics 2015, 4, 455-466. [CrossRef] [PubMed]

146. Derzsi, L.; Kaminski, T.S.; Garstecki, P. Antibiograms in five pipetting steps: Precise dilution assays in sub-microliter volumes with a conventional pipette. Lab Chip 2016, 16, 893-901. [CrossRef] [PubMed]

147. Leonard, H.; Halachmi, S.; Ben-Dov, N.; Nativ, O.; Segal, E. Unraveling Antimicrobial Susceptibility of Bacterial Networks on Micropillar Architectures Using Intrinsic Phase-Shift Spectroscopy. ACS Nano 2017, 11, 6167-6177. [CrossRef] [PubMed] 
148. Tang, M.; Huang, X.; Chu, Q.; Ning, X.; Wang, Y.; Kong, S.K.; Zhang, X.; Wang, G.; Ho, H.P. A linear concentration gradient generator based on multi-layered centrifugal microfluidics and its application in antimicrobial susceptibility testing. Lab Chip 2018, 17. [CrossRef] [PubMed]

149. Li, B.; Qiu, Y.; Glidle, A.; Mcllvenna, D.; Luo, Q.; Cooper, J.; Shi, H.C.; Yin, H. Gradient microfluidics enables rapid bacterial growth inhibition testing. Anal. Chem. 2014, 86, 3131-3137. [CrossRef] [PubMed]

150. Smith, K.P.; Richmond, D.L.; Brennan-Krohn, T.; Elliott, H.L.; Kirby, J.E. Development of MAST: A Microscopy-Based Antimicrobial Susceptibility Testing Platform. SLAS Technol. 2017, 22, 662-674. [CrossRef] [PubMed]

151. Choi, J.; Yoo, J.; Kim, K.J.; Kim, E.G.; Park, K.O.; Kim, H.; Kim, H.; Jung, H.; Kim, T.; Choi, M.; et al. Rapid drug susceptibility test of Mycobacterium tuberculosis using microscopic time-lapse imaging in an agarose matrix. Appl. Microbiol. Biotechnol. 2016, 100, 2355-2365. [CrossRef] [PubMed]

152. Boedicker, J.Q.; Li, L.; Kline, T.R.; Ismagilov, R.F. Detecting bacteria and determining their susceptibility to antibiotics by stochastic confinement in nanoliter droplets using plug-based microfluidics. Lab Chip 2008, 8, 1265-1272. [CrossRef] [PubMed]

153. Choi, J.; Jung, Y.G.; Kim, J.; Kim, S.; Jung, Y.; Na, H.; Kwon, S. Rapid antibiotic susceptibility testing by tracking single cell growth in a microfluidic agarose channel system. Lab Chip 2013, 13, 280-287. [CrossRef] [PubMed]

154. Kalashnikov, M.; Lee, J.C.; Campbell, J.; Sharon, A.; Sauer-Budge, A.F. A microfluidic platform for rapid, stress-induced antibiotic susceptibility testing of Staphylococcus aureus. Lab Chip 2012, 12, 4523-4532. [CrossRef] [PubMed]

155. Price, C.S.; Kon, S.E.; Metzger, S. Rapid antibiotic susceptibility phenotypic characterization of Staphylococcus aureus using automated microscopy of small numbers of cells. J. Microbiol. Methods 2014, 98, 50-58. [CrossRef] [PubMed]

156. Choi, J.; Yoo, J.; Lee, M.; Kim, E.G.; Lee, J.S.; Lee, S.; Joo, S.; Song, S.H.; Kim, E.C.; Lee, J.C.; et al. A rapid antimicrobial susceptibility test based on single-cell morphological analysis. Sci. Transl. Med. 2014, 6, 267ra174. [CrossRef] [PubMed]

157. Hou, Z.; An, Y.; Hjort, K.; Hjort, K.; Sandegren, L.; Wu, Z. Time lapse investigation of antibiotic susceptibility using a microfluidic linear gradient 3D culture device. Lab Chip 2014, 14, 3409-3418. [CrossRef] [PubMed]

158. Matsumoto, Y.; Sakakihara, S.; Grushnikov, A.; Kikuchi, K.; Noji, H.; Yamaguchi, A.; Iino, R.; Yagi, Y.; Nishino, K. A Microfluidic Channel Method for Rapid Drug-Susceptibility Testing of Pseudomonas aeruginosa. PLoS ONE 2016, 11, e0148797. [CrossRef] [PubMed]

159. Hansen, K.M.; Thundat, T. Microcantilever biosensors. Methods 2005, 37, 57-64. [CrossRef] [PubMed]

160. Fritz, J. Cantilever biosensors. Analyst 2008, 133, 855-863. [CrossRef] [PubMed]

161. Willaert, R.; Kasas, S.; Devreese, B.; Dietler, G. Yeast nanobiotechnology. Fermentation 2016, 2, 18. [CrossRef]

162. Braun, T.; Ghatkesar, M.K.; Backmann, N.; Grange, W.; Boulanger, P.; Letellier, L.; Lang, H.P.; Bietsch, A.; Gerber, C.; Hegner, M. Quantitative time-resolved measurement of membrane protein-ligand interactions using microcantilever array sensors. Nat. Nanotechnol. 2009, 4, 179-185. [CrossRef] [PubMed]

163. Godin, M.; Tabard-Cossa, V.; Miyahara, Y.; Monga, T.; Williams, P.J.; Beaulieu, L.Y.; Bruce Lennox, R.; Grutter, P. Cantilever-based sensing: The origin of surface stress and optimization strategies. Nanotechnology 2010, 21, 75501. [CrossRef] [PubMed]

164. Godin, M.; Delgado, F.F.; Son, S.; Grover, W.H.; Bryan, A.K.; Tzur, A.; Jorgensen, P.; Payer, K.; Grossman, A.D.; Kirschner, M.W.; et al. Using buoyant mass to measure the growth of single cells. Nat. Methods 2010, 7, 387-390. [CrossRef] [PubMed]

165. Ndieyira, J.W.; Watari, M.; Barrera, A.D.; Zhou, D.; Vögtli, M.; Batchelor, M.; Cooper, M.A.; Strunz, T.; Horton, M.A.; Abell, C.; et al. Nanomechanical detection of antibiotic-mucopeptide binding in a model for superbug drug resistance. Nat. Nanotechnol. 2008, 3, 691-696. [CrossRef] [PubMed]

166. Lang, H.P.; Baller, M.K.; Berger, R.; Gerber, C.; Gimzewski, J.K.; Battiston, F.M.; Fornaro, P.; Ramseyer, J.P.; Meyer, E.; Guntherodt, H.J. An artificial nose based a micromechanical cantilever array. Anal. Chim. Acta 1999, 393, 59-65. [CrossRef]

167. Braun, T.; Barwich, V.; Ghatkesar, M.K.; Bredekamp, A.H.; Gerber, C.; Hegner, M.; Lang, H.P. Micromechanical mass sensors for biomolecular detection in a physiological environment. Phys. Rev. E Stat. Nonlin. Soft Matter Phys. 2005, 72, 031907. [CrossRef] [PubMed] 
168. Hosaka, S.; Chiyoma, T.; Ikeuchi, A.; Okano, H.; Sone, H.; Izumi, T. Possibility of a femtogram mass biosensor using a self-sensing cantilever. Curr. Appl. Phys. 2006, 6, 384-388. [CrossRef]

169. Liu, Y.; Schweizerb, L.M.; Wanga, W.; Reubena, R.L.; Schweizer, M.; Shu, W. Label-free and real-time monitoring of yeast cell growth by the bending of polymer microcantilever biosensors. Sens. Actuator B-Chem. 2013, 178, 621-626. [CrossRef]

170. Bryan, A.K.; Goranov, A.; Amon, A.; Manalis, S.R. Measurement of mass, density, and volume during the cell cycle of yeast. Proc. Natl. Acad. Sci. USA 2010, 107, 999-1004. [CrossRef] [PubMed]

171. Cermak, N.; Olcum, S.; Delgado, F.F.; Wasserman, S.C.; Payer, K.R.; Murakami, M.A.; Knudsen, S.M.; Kimmerling, R.J.; Stevens, M.M.; Kikuchi, Y.; et al. High-throughput measurement of single-cell growth rates using serial microfluidic mass sensor arrays. Nat. Biotechnol. 2016, 34, 1052-1059. [CrossRef] [PubMed]

172. Burg, T.P.; Godin, M.; Knudsen, S.M.; Shen, W.; Carlson, G.; Foster, J.S.; Babcock, K.; Manalis, S.R. Weighing of biomolecules, single cells and single nanoparticles in fluid. Nature 2007, 446, 1066-1069. [CrossRef] [PubMed]

173. Park, K.; Jang, J.; Irimia, D.; Sturgis, J.; Lee, J.; Robinson, J.P.; Toner, M.; Bashir, R. 'Living cantilever arrays' for characterization of mass of single live cells in fluids. Lab Chip 2008, 8, 1034-1041. [CrossRef] [PubMed]

174. Bryan, A.K.; Hecht, V.C.; Shen, W.; Payer, K.; Grover, W.H.; Manalis, S.R. Measuring single cell mass, volume, and density with dual suspended microchannel resonators. Lab Chip 2014, 14, 569-576. [CrossRef] [PubMed]

175. Nugaeva, N.; Gfeller, K.Y.; Backmann, N.; Lang, H.P.; Düggelin, M.; Hegner, M. Micromechanical cantilever array sensors for selective fungal immobilization and fast growth detection. Biosens. Bioelectron. 2005, 21, 849-856. [CrossRef] [PubMed]

176. Stupar, P. Atomic Force Microscopy of Biological Systems: Quantitative Imaging and Nanomotion Detection. Ph.D. Thesis, EPFL Scientific Publications, Lausanne, Switzerland, 2018.

177. Longo, G.; Alonso-Sarduy, L.; Rio, L.M.; Bizzini, A.; Trampuz, A.; Notz, J.; Dietler, G.; Kasas, S. Rapid detection of bacterial resistance to antibiotics using AFM cantilevers as nanomechanical sensors. Nat. Nanotechnol. 2013, 8, 522-526. [CrossRef] [PubMed]

178. Stupar, P.; Opota, O.; Longo, G.; Prod'hom, G.; Dietler, G.; Greub, G.; Kasas, S. Nanomechanical sensor applied to blood culture pellets: A fast approach to determine the antibiotic susceptibility against agents of bloodstream infections. Clin. Microbiol. Infect. 2017, 23, 400-405. [CrossRef] [PubMed]

179. Stupar, P.; Yvanoff, C.; Chomicki, W.; Dietler, G.; Kasas, S.; Willaert, R. Exploring Nanoscale Motions of Yeast Cells. In Proceedings of the XIX Annual Linz Winter Workshop, Linz, Austria, 3-6 February 2017.

180. Vanden Boer, P.; Stupar, P.; Chomicki, W.; Dietler, G.; Kasas, S.; Willaert, R. Nanomotion Detection of Single Yeast Cell Growth. In Proceedings of the XX Annual Linz Winter Workshop, Linz, Austria, 2-5 February 2018.

181. Morones, J.R.; Elechiguerra, J.L.; Camacho, A.; Ramirez, J.T. The bactericidal effect of silver nanoparticles. Nanotechnology 2005, 16, 2346-2353. [CrossRef] [PubMed]

182. Kim, J.S.; Kuk, E.; Yu, K.N.; Kim, J.H.; Park, S.J.; Lee, H.J.; Kim, S.H.; Park, Y.K.; Park, Y.H.; Hwang, C.Y.; et al. Antimicrobial effects of silver nanoparticles. Nanomed. Nanotechnol. Biol. Med. 2007, 3, 95-101. [CrossRef] [PubMed]

183. Ahamed, M.; Alsalhi, M.S.; Siddiqui, M.K. Silver nanoparticle applications and human health. Clin. Chim. Acta 2010, 411, 1841-1848. [CrossRef] [PubMed]

184. Chen, X.; Schleusener, H.J. Nanosilver: A nanoproduct in medical application. Toxicol. Lett. 2008, 176, 1 e12. [CrossRef] [PubMed]

185. Rai, M.; Yadav, A.; Gade, A. Silver nanoparticles as a new generation of antimicrobials. Biotechnol. Adv. 2009, 27, 76-83. [CrossRef] [PubMed]

186. De Jong, W.H.; Van Der Ven, L.T.; Sleijffers, A.; Park, M.V.; Jansen, E.H.; Van Loveren, H.; Vandebriel, R.J. Systemic and immunotoxicity of silver nanoparticles in an intravenous 28 days repeated dose toxicity study in rats. Biomaterials 2013, 34, 8333-8343. [CrossRef] [PubMed]

187. Durán, N.; Durán, M.; de Jesus, M.B.; Seabra, A.B.; Fávaro, W.J.; Nakazato, G. Silver nanoparticles: A new view on mechanistic aspects on antimicrobial activity. Nanomedicine 2016, 12, 789-799. [CrossRef] [PubMed]

188. Ahamed, M.; Karns, M.; Goodson, M.; Rowe, J.; Hussain, S.M.; Schlager, J.J.; Hong, Y. DNA damage response to different surface chemistry of silver nanoparticles in mammalian cells. Toxicol. Appl. Pharmacol. 2008, 233, 404-410. [CrossRef] [PubMed]

189. Kawata, K.; Osawa, M.; Okabe, S. In vitro toxicity of silver nanoparticles at noncytotoxic doses to HepG2 human hepatoma cells. Environ. Sci. Technol. 2009, 43, 6046-6051. [CrossRef] [PubMed] 
190. AshaRani, P.V.; Low Kah Mun, G.; Hande, M.P.; Valiyaveettil, S. Cytotoxicity and genotoxicity of silver nanoparticles in human cells. ACS Nano 2009, 3, 279-290. [CrossRef] [PubMed]

191. Panáček, A.; Kvítek, L.; Smékalová, M.; Večeřová, R.; Kolář, M.; Röderová, M.; Dyčka, F.; Šebela, M.; Prucek, R.; Tomanec, O; et al. Bacterial resistance to silver nanoparticles and how to overcome it. Nat. Nanotechnol. 2018, 13, 65-71. [CrossRef] [PubMed]

192. Ammar, H.A.; El-Desouky, T.A. Green synthesis of nanosilver particles by Aspergillus terreus HA1N and Penicillium expansum HA2N and its antifungal activity against mycotoxigenic fungi. J. Appl. Microbiol. 2016, 121, 89-100. [CrossRef] [PubMed]

193. Xue, B.; He, D.; Gao, S.; Wang, D.; Yokoyama, K.; Wang, L. Biosynthesis of silver nanoparticles by the fungus Arthroderma fulvum and its antifungal activity against genera of Candida, Aspergillus and Fusarium. Int. J. Nanomedicine 2016, 11, 1899-1906. [CrossRef] [PubMed]

194. Khan, N.T.; Jameel, N. Antifungal Activity of Silver Nanoparticles Produced from Fungus, Penicillium fellutanum at Different pH. J. Microb. Biochem. Technol. 2016, 8, 5. [CrossRef]

195. Fukushima, K.; Liu, S.; Wu, H.; Engler, A.C.; Coady, D.J.; Maune, H.; Pitera, J.; Nelson, A.; Wiradharma, N.; Venkataraman, S.; et al. Supramolecular high-aspect ratio assemblies with strong antifungal activity. Nat. Commun. 2013, 4, 2861. [CrossRef] [PubMed]

196. Esteban-Tejeda, L.; Malpartida, F.; Esteban-Cubillo, A.; Pecharromán, C.; Moya, J.S. Antibacterial and antifungal activity of a soda-lime glass containing copper nanoparticles. Nanotechnology 2009, 20, 505701. [CrossRef] [PubMed]

197. Paulo, C.S.; Vidal, M.; Ferreira, L.S. Antifungal nanoparticles and surfaces. Biomacromolecules 2010, 11, 2810-2817. [CrossRef] [PubMed]

198. Perfect, J.R. Fungal virulence genes as targets for antifungal chemotherapy. Antimicrob. Agents Chemoth. 1996, 40, 1577-1583.

199. Kitamura, A.; Someya, K.; Hata, M.; Nakajima, R.; Takemura, M. Discovery of a small-molecule inhibitor of 3-1,6-glucan synthesis. Antimicrob. Agents Chemoth. 2009, 53, 670-677. [CrossRef] [PubMed]

200. Baxter, B.K.; DiDone, L.; Ogu, D.; Schor, S.; Krysan, D.J. Identification, in vitro activity and mode of action of phosphoinositide-dependent-1 kinase inhibitors as antifungal molecules. ACS Chem. Biol. 2011, 6, 502-510. [CrossRef] [PubMed]

(C) 2018 by the author. Licensee MDPI, Basel, Switzerland. This article is an open access article distributed under the terms and conditions of the Creative Commons Attribution (CC BY) license (http://creativecommons.org/licenses/by/4.0/). 